\title{
The Effect of Atmospheric Forcing Resolution on Delivery of Ocean Heat to the Antarctic Floating Ice Shelves*, ${ }^{+}$
}

\author{
Michael S. DinNiMAN AND JOHN M. KLINCK \\ Center for Coastal Physical Oceanography, Old Dominion University, Norfolk, Virginia \\ Le-Sheng BAi, David H. Bromwich, AND Keith M. Hines \\ Polar Meteorology Group, Byrd Polar Research and Climate Center, The Ohio State University, Columbus, Ohio \\ DAVID M. HOLLAND \\ Courant Institute of Mathematical Sciences, New York University, New York, New York
}

(Manuscript received 23 May 2014, in final form 23 April 2015)

\begin{abstract}
Oceanic melting at the base of the floating Antarctic ice shelves is now thought to be a more significant cause of mass loss for the Antarctic ice sheet than iceberg calving. In this study, a 10-km horizontal-resolution circum-Antarctic ocean-sea ice-ice shelf model [based on the Regional Ocean Modeling System (ROMS)] is used to study the delivery of ocean heat to the base of the ice shelves. The atmospheric forcing comes from the ERA-Interim reanalysis ( $\sim 80$-km resolution) and from simulations using the polar-optimized Weather Research and Forecasting Model (30-km resolution), where the upper atmosphere was relaxed to the ERAInterim reanalysis. The modeled total basal ice shelf melt is low compared to observational estimates but increases by $14 \%$ with the higher-resolution winds and just $3 \%$ with both the higher-resolution winds and atmospheric surface temperatures. The higher-resolution winds lead to more heat being delivered to the ice shelf cavities from the adjacent ocean and an increase in the efficiency of heat transfer between the water and the ice. The higher-resolution winds also lead to changes in the heat delivered from the open ocean to the continental shelves as well as changes in the heat lost to the atmosphere over the shelves, and the sign of these changes varies regionally. Addition of the higher-resolution temperatures to the winds results in lowering, primarily during summer, the wind-driven increase in heat advected into the ice shelf cavities due to colder summer air temperatures near the coast.
\end{abstract}

\section{Introduction}

Mass loss from the Antarctic ice sheet has been shown to be accelerating recently (Chen et al. 2009; Velicogna 2009; Rignot et al. 2011; McMillan et al. 2014), and the most significant changes in the thickness of the grounded portions of the ice sheet are observed at the coastal

\footnotetext{
* Supplemental information related to this paper is available at the Journals Online website: http://dx.doi.org/10.1175/JCLI-D-14-00374.s1. 1538.

${ }^{+}$Byrd Polar Research and Climate Center Contribution Number

Corresponding author address: Michael S. Dinniman, Center for Coastal Physical Oceanography, Old Dominion University, 4111 Monarch Way, Norfolk, VA 23508.

E-mail: msd@ccpo.odu.edu
}

margins (Pritchard et al. 2009). The floating Antarctic ice shelves begin where the ice sheets flow off the landmass and out over the ocean. Ice shelves have been shown to buttress the outlet glaciers of the ice sheet (DeAngelis and Skvarca 2003; Dupont and Alley 2005; Schoof 2007), and thus changes in the mass of the ice shelves would result in changes in the flow of continental ice off the land. Until recently, it was believed that the most significant loss of mass from the ice shelves was from iceberg calving. However, slightly more mass is now estimated to be lost from basal melting (Depoorter et al. 2013; Rignot et al. 2013).

Ice shelf basal melting can be characterized by three modes (Jacobs et al. 1992). In mode 1 melting, highsalinity shelf water (HSSW), a cold, salty water mass formed on Antarctic continental shelves mostly due to brine rejection from sea ice formation, intrudes into the 
bottom of cavities below the ice shelves. The temperature of HSSW is close to the freezing point of seawater at the surface, but because of the depression of the freezing point of water with pressure $\left[\sim 0.76^{\circ} \mathrm{C}(1000 \mathrm{~m})^{-1}\right.$; Foldvik and Kvinge 1974], HSSW can cause basal melt underneath deep ice shelves, especially at the deepest locations near the grounding line. In mode 2 melting, relatively warm $\left(T>0^{\circ} \mathrm{C}\right)$ Circumpolar Deep Water (CDW) intrudes onto the continental shelves and underneath the ice shelves and, since the water can be $>4^{\circ} \mathrm{C}$ warmer than the in situ freezing point, can lead to rapid melting. Finally, in mode 3 melting, warm surface waters enter the ice cavity near the surface, causing melting near the ice shelf front.

The core of the Antarctic Circumpolar Current (ACC) that surrounds Antarctica consists of $\mathrm{CDW}$, which is a mixture of deep water from all of the world's oceans (Orsi et al. 1995). This water, with temperatures as warm as $1.8^{\circ} \mathrm{C}$, is located next to the continental shelf break along the Bellingshausen and parts of the Amundsen Seas (roughly $130^{\circ}-80^{\circ} \mathrm{W}$ ), where the edge of the West Antarctic Ice Sheet is within $100 \mathrm{~km}$ of the continental shelf break. CDW is observed to intrude onto the continental shelf, and advection of this warm water across the continental shelf to the base of ice shelves is thought to supply most of the heat involved in basal melt along the coastal Amundsen (Jacobs et al. 1996, 2011, 2012, 2013; Jenkins et al. 1997, 2010; Hellmer et al. 1998) and Bellingshausen Seas (Potter and Paren 1985; Talbot 1988; Jenkins and Jacobs 2008). Increased intrusion of this warm oceanic water under ice shelves is hypothesized to be an important cause for the recently observed increased rate of ice thinning (Payne et al. 2004; Shepherd et al. 2004; Pritchard et al. 2012), although other studies (Holland et al. 2010; Padman et al. 2012) suggest that changes in the melting of the Bellingshausen ice shelves are more influenced by variability of the upper-ocean conditions over the nearby continental shelves than by changes in the flux of oceanic CDW across the continental shelf.

The three melting modes overlap in various ways for different ice shelves, but in order to accurately simulate the current and future basal melt over all the Antarctic ice shelves, it is necessary to be able to model not only the iceocean interactions beneath the ice shelves, but also all the processes in the open ocean involved in the delivery of heat in each mode. Mode 1 melting, for example, requires accurate simulation of the interplay between wind and sea ice that creates coastal polynyas in the Ross Sea (Bromwich and Kurtz 1984; Zwally et al. 1985; Bromwich et al.1993; Bromwich et al. 1998), Weddell Sea (Kottmeier and Engelbart 1992; Haid and Timmermann 2013), and along the East Antarctic coast (Massom et al. 1998), where HSSW is created by sea ice freezing (Jacobs and Comiso 1989; Markus et al. 1998; Petty et al. 2014). The dynamics of intrusions of CDW onto the continental shelf, responsible for mode 2 melting, are still under investigation (Klinck and Dinniman 2010). Vertical mixing on the shelf, which changes CDW heat content, must also be properly represented. Nearshore surface processes that lead to warming of surface waters that can still penetrate below the ice shelf fronts (Hattermann et al. 2012; Stern et al. 2013; Arzeno et al. 2014) need to be accurately modeled in order to account for mode 3 melting.

A critical aspect of modeling the different processes in the open ocean that affect ice shelf basal melt is the horizontal resolution of both the ocean model and the atmospheric forcing. Because of the weak stratification in coastal Antarctic waters, the internal radius of deformation on many Antarctic continental shelves is about 4-5 km (Nicholls and Makinson 1998; Hofmann and Klinck 1998; Hallberg 2013). To properly resolve eddies in the Antarctic coastal ocean, a model horizontal resolution on scales of $\sim 1 \mathrm{~km}$ is necessary. Most recent regional models that include ice shelves have larger grid spacing (Galton-Fenzi et al. 2012; Mueller et al. 2012; Timmermann et al. 2012; Kusahara and Hasumi 2013; Robertson 2013); however, 1-km resolution has been shown in idealized cases to be important for heat delivery to the ice shelf cavities for both mode 1 (Årthun et al. 2013) and mode 2 (St-Laurent et al. 2013) melting.

In the atmosphere, shifts in the mean position of the westerlies over the Southern Ocean have a significant effect on the modeled heat transport onto the Antarctic continental shelf (Spence et al. 2014). However, several global reanalysis products already have small enough horizontal resolution to accurately simulate storms and wind variability over the open Southern Ocean (Li et al. 2013). Where finer horizontal resolution is critical is in coastal areas because of the influence of topography. Regional atmospheric models around the Antarctic show that reducing the grid spacing from that of the current generation of global reanalyses $(\sim 200-60 \mathrm{~km})$ to tens of kilometers markedly improves the simulation of the coastal winds (Bromwich et al. 2005, 2013). Improvements in the modeled coastal winds due to better resolution have been shown to increase the fidelity of simulations of coastal polynyas in the Weddell (Hollands et al. 2013) and Ross Seas (Petrelli et al. 2008; Mathiot et al. 2012) and also improved the simulated properties of HSSW in the Ross Sea (Mathiot et al. 2012), although that comparison can be difficult because of the lack of observations during HSSW creation. Better simulation of the coastal sea ice affects all three modes of melting through more accurate creation of HSSW on the continental shelf (affecting mode 1 melting); improved vertical mixing of heat out of CDW on the continental shelf (mode 2; e.g., Holland et al. 2010); and improved representation of, and 
surface heating in, coastal summer ice-free areas (mode 3).

One of the major goals of the Atmosphere-Ocean Coupling Causing Ice Shelf Melt in Antarctica (ACCIMA) project (http://polarmet.osu.edu/ACCIMA) is to quantify the importance of model horizontal resolution (atmosphere and ocean) on the delivery of oceanic heat to the base of the floating ice shelves. The primary objective of this study is to examine the sensitivity of simulated ice shelf basal melt to the resolution of the atmospheric forcing through the use of a 10-km-resolution circum-Antarctic ocean-sea ice-ice shelf Regional Ocean Modeling System (ROMS) model. The atmospheric forcing for the base simulation is from the ERA-Interim reanalysis $(\sim 80-\mathrm{km}$ resolution). Other simulations use wind and temperature from a 30-km resolution downscaling of the ERA-Interim reanalysis using the polar-optimized Weather Research and Forecasting (PWRF) Model.

\section{Circulation model and experiments}

\section{a. Ocean-sea ice-ice shelf model}

The ocean-sea ice-ice shelf model used is ROMS, which is a primitive-equation, finite-difference model with a terrainfollowing vertical coordinate system (Haidvogel et al. 2008; Shchepetkin and McWilliams 2009). The circum-Antarctic model domain (Fig. 1) includes the entire Antarctic continental shelf including the portion $(\sim 35 \%)$ underneath the floating ice shelves. The domain extends northward from the continent past the Subantarctic Front and includes much of the Subtropical Front (Fig. 1). The model boundary is well north of any winter sea ice. The grid uses a polar stereographic projection with a horizontal grid spacing of $10 \mathrm{~km}$, and there are 32 vertical layers with smaller spacing near the surface and bottom. Note that previous regional models, representing both warm and cold continental shelves, used only 24 layers but could still adequately simulate vertical profiles of temperature and salinity near and below ice shelves (Dinniman et al. 2011). The model topography includes the elevation of the bedrock and the base of several ice shelves and comes from the global 1-min Refined Topography (RTopo-1) dataset (Timmermann et al. 2010).

Sea ice is simulated with a dynamic sea ice model (Budgell 2005) contained in ROMS based on two-layer ice thermodynamics (and a molecular sublayer beneath the sea ice) described by Mellor and Kantha (1989) and Häkkinen and Mellor (1992). A snow layer is included, as well as a conversion of snow to ice when the snow-ice interface is below sea level, along with a simple estimate of frazil ice production (Steele et al. 1989). Ice dynamics are based on an elastic-viscous-plastic rheology (Hunke and Dukowicz 1997; Hunke 2001). The ice model only has one

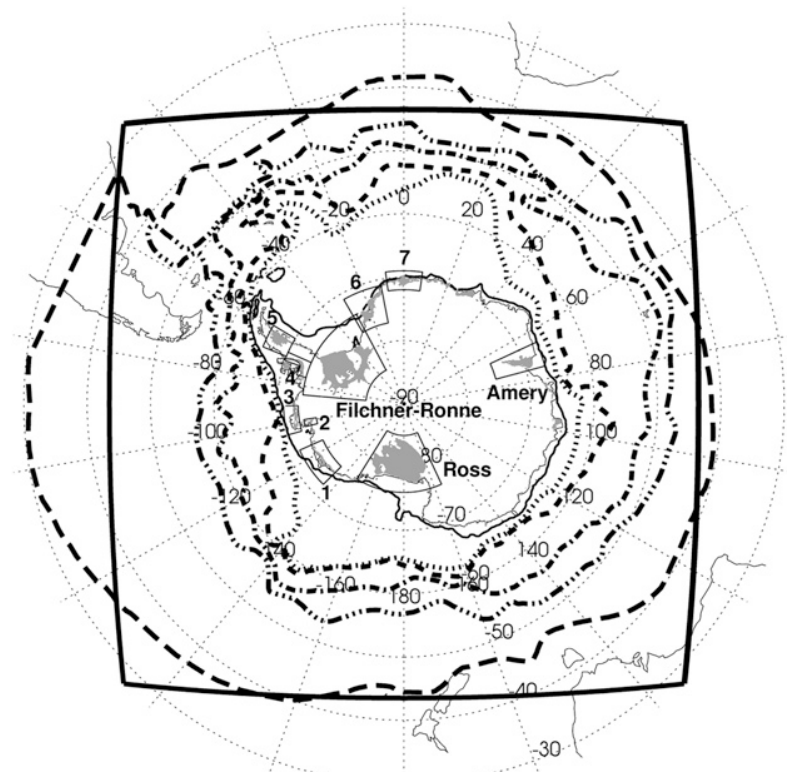

FIG. 1. Southern Ocean model domain (outer thick black box) showing ice shelves (shaded areas), regional domains for ice shelf calculations [boxes around the three largest ice shelves (labeled) and 1) Getz, 2) Pine Island Glacier, 3) Abbot, 4) George VI, 5) Larsen C, 6) Brunt and Riiser-Larsen, and 7) Fimbulisen and Jelbart ice shelves], location of the shelf break around Antarctica (represented by 1000-m isobath; thin solid black line), and climatological locations (dashed lines; from Orsi et al. 1995) of the ACC fronts. The ACC fronts from outermost inward are the Subtropical Front, the Subantarctic Front, the Polar Front, the Southern ACC Front, and the southern boundary of the ACC.

thickness category, but this appears to be adequate as there is little multiyear ice in the Antarctic (Comiso 2010), and this model has proven to accurately simulate sea ice concentrations in other regional implementations around Antarctica (Dinniman et al. 2011; Stern et al. 2013). The ice shelves in the model are static; there is no thinning (or thickening) of the ice shelf, nor any iceberg calving parameterization or moving icebergs. The model does include the mechanical and thermodynamic effects of ice shelves on the waters beneath as described in Dinniman et al. (2007), except that the heat and salt transfer coefficients are no longer constant but are functions of the friction velocity (Holland and Jenkins 1999). Open ocean momentum, heat, and freshwater (imposed as a salt flux) fluxes for the model are calculated from the COARE 3.0 bulk flux algorithm (Fairall et al. 2003) and there is no relaxation of surface temperature or salinity. Ocean tides are not included in these simulations.

Vertical momentum and tracer mixing were computed using the K-profile parameterization (KPP; Large et al. 1994) implemented in ROMS with a modification (Dinniman et al. 2011). The surface boundary layer depth under stabilizing conditions with nonzero surface shortwave flux was set 
TABLE 1. Summary of model simulations. All simulations were run for 10 years with the forcing for the year 2010 being repeated each year.

\begin{tabular}{lll}
\hline \hline Simulation & \multicolumn{1}{c}{10 -m winds } & \multicolumn{1}{c}{$\begin{array}{c}\text { 2-m atmospheric } \\
\text { temperature }\end{array}$} \\
\hline ERA-Int & ERA-Interim $(\sim 80 \mathrm{~km})$ & ERA-Interim $(\sim 80 \mathrm{~km})$ \\
PWRF & Polar WRF $(30 \mathrm{~km})$ & ERA-Interim $(\sim 80 \mathrm{~km})$ \\
PWRF + & Polar WRF $(30 \mathrm{~km})$ & Polar WRF $(30 \mathrm{~km})$ \\
\hline
\end{tabular}

to a minimum depth, equal to the directly wind-forced minimum depth under stable conditions in a KrausTurner bulk mixed-layer model (Niiler and Kraus 1977; Dinniman et al. 2012). The third-order upstream horizontal momentum advection scheme used is naturally dissipative and no additional explicit horizontal momentum mixing was required. Explicit Laplacian horizontal mixing of tracers is imposed along geopotential surfaces with a small $\left(5 \mathrm{~m}^{2} \mathrm{~s}^{-1}\right)$ coefficient.

Initial conditions of temperature and salinity are taken from the World Ocean Atlas 2009 (WOA09; Locarnini et al. 2010) and the WOA09 values, which are strongly summer biased over the Antarctic continental shelf, are simply extrapolated southward from the ice shelf front for any ice shelf cavities. The lateral boundary conditions for temperature and salinity relax to monthly climatologies from WOA09 over the 10 grid points closest to the open boundaries using the flow relaxation scheme of Martinsen and Engedahl (1987). Boundary values of depth-averaged velocity and sea surface height are from monthly climatologies derived from the Simple Ocean Data Assimilation (SODA, version 1.4.2) ocean reanalysis (Carton and Giese 2008). The Flather (1976) scheme is used for the depth-averaged velocities at the open boundaries, and the three-dimensional velocities at the boundaries are computed using the radiation scheme of Marchesiello et al. (2001). The model open boundaries are north of any sea ice observed during the satellite era (1979 to present), so no sea ice boundary information is necessary.

\section{b. Atmospheric forcing}

The base simulation (ERA-Int, Table 1) uses the ERAInterim reanalysis (Dee et al. 2011) for most of the necessary atmospheric forcing. Reanalysis forcing for the model includes $10-\mathrm{m}$ height winds every $6 \mathrm{~h}, 2-\mathrm{m}$ height air temperatures every $12 \mathrm{~h}$, and monthly values of sea level pressure and relative humidity (computed from dewpoint). A monthly climatology of precipitation is taken from the Global Precipitation Climatology Project (version 2.2; Adler et al. 2003), and cloud fraction is taken from the International Satellite Cloud Climatology Project (version D2; Rossow et al. 1996). Atmospheric data were only taken from the year 2010, and the 10-yr model run was forced by continuously repeating the year 2010 conditions so as to discern if interannual changes in the model were due to model drift or spinup as opposed to externally forced interannual variability. The year 2010 was chosen primarily because it was a "typical" year in terms of ice extent around the continent: all months of 2010 were between $92 \%$ and $108 \%$ of the climatological (1981-2010) ice extent of each month.

The ERA-Interim reanalysis has a horizontal spectral resolution of T255, which is approximately $80 \mathrm{~km}$, and the model fields were provided on a $0.75^{\circ}$ grid. To obtain higher-resolution atmospheric forcing, a stand-alone simulation with PWRF (e.g., Bromwich et al. 2013; Hines et al. 2015) was run over the same domain as the ocean simulation for the same year (2010), but with a 30-km horizontal spacing and 70 vertical levels. The PWRF simulation is forced by the same sea surface temperature (SST) and sea ice conditions used in ERA-Interim. The PWRF run was nudged to the ERA-Interim reanalysis so that not only were all the atmospheric variables on the lateral boundaries continuously updated from ERA-Interim, but spectral nudging was used throughout the interior (e.g., Glisan et al. 2013). Horizontal wind, temperature, and geopotential height were nudged to ERA-Interim fields at spatial scales larger than wavenumber $7(>1500 \mathrm{~km})$ for all of the model atmosphere above the planetary boundary layer $(\sim 900 \mathrm{mb})$, thus ensuring that the large-scale structure of the atmospheric circulation is consistent with the reanalysis, but the atmospheric mesoscale circulation is allowed to evolve freely.

\section{c. Simulations}

The base simulation (ERA-Int, Table 1) was initialized on 1 January 2010 and was run for 10 years using the same 2010 forcing for each year. A second 10-yr simulation (PWRF) was forced by 6 hourly winds from the 2010 PWRF simulation, but with all other forcing the same as the base case. Finally, a third 10-yr simulation (PWRF+) was forced by winds and atmospheric temperatures from the PWRF simulation. These simulations were typically run on 64 cores and the run time was 19 days. The total combined basal melt rate for all the ice shelves and the melt rate for each of the individual ice shelves that was examined reached a steady state within 3-4 years (sometimes sooner). Unless explicitly stated otherwise, all results are from the last 5 years of each simulation.

\section{Results}

\section{a. ERA-Int simulation of the Southern Ocean and ice shelf basal melt}

Volume transport through Drake Passage over the last 5 years (and also over the entire 10 years) of the simulation 
is $143 \pm 10 \mathrm{~Sv}\left(1 \mathrm{~Sv}=10^{6} \mathrm{~m}^{3} \mathrm{~s}^{-1}\right)$, which matches quite well with the mean and variability of observational estimates of $134 \pm 11 \mathrm{~Sv}$ (Cunningham et al. 2003) and $141 \pm 13$ Sv (Koenig et al. 2014). The ACC volume transport is likely important to on-shelf heat transport, especially where the ACC impinges on the shelf break (e.g., Amundsen-Bellingshausen sector), as fully eddy-resolving models have shown a relationship between the shelf-break jet speed and the on-shelf heat transport (e.g., St-Laurent et al. 2013). Eddy kinetic energy (EKE; Fig. 2) computed for a model layer near, but below, the surface (layer 26 : $\sim 100 \mathrm{~m}$ deep over the abyssal ocean and $20 \mathrm{~m}$ deep over the continental shelf), matches well the magnitude and locations of enhanced variability along the ACC and the western boundary current along Argentina shown in satellite estimates from altimetry (Fig. 2). The EKE in the model takes about 1.5 years to fully develop (not shown). The mean model EKE for the 10-km resolution model is 2.5 times greater than in a test simulation of the same model at $20-\mathrm{km}$ resolution. While the current $10-\mathrm{km}$ model resolution is not eddy resolving on the Antarctic continental shelves, it well represents the eddy variability over the rest of the Southern Ocean.

The model monthly SST is compared (Fig. 3 and Fig. S1 in the online supplement) to three different estimates of the ocean SST [WOA09, SODA, and the Estimating the Circulation and Climate of the Ocean, phase II (ECCO2), ocean reanalysis (Menemenlis et al. 2008)]. Root-meansquare error (RMSE) over the entire model domain is $1.15^{\circ} \mathrm{C}$ when compared to WOA09 (source of the model lateral boundary conditions), $1.42^{\circ} \mathrm{C}$ for SODA, and $1.46^{\circ} \mathrm{C}$ for $\mathrm{ECCO} 2$. The error peaks in summer during the period of the strongest meridional SST gradients but does not grow over time. The model average salinity over the continental shelves over the last 5 years only changes by $10^{-4} \mathrm{yr}^{-1}$, which is well below the annual variation (standard deviation $=1.89 \times 10^{-2}$ ) and any measured freshening over either the Ross Sea $\left(3 \times 10^{-3} \mathrm{yr}^{-1}\right.$; Jacobs and Giulivi 2010) or northwestern Weddell Sea $\left(5 \times 10^{-3} \mathrm{yr}^{-1}\right.$; Hellmer et al. 2011) continental shelves, thus indicating that the processes that govern water mass formation on the continental shelves are not significantly out of balance in the simulation. The sea ice area over the entire model domain matches extremely well with observations (Fig. 4) and shows little sign of drift over time. Model sea ice extent in February and August (Fig. 5) does not quite match observations in a few areas (especially the summer extent in the Ross Sea and the lack of summer sea ice along the East Antarctic coast), but the mean patterns generally compare well.

The total modeled annual average ice shelf basal melt around the entire continent is $664 \mathrm{Gt} \mathrm{yr}^{-1}$ with a very strong seasonal cycle (Fig. 6), but little year to year

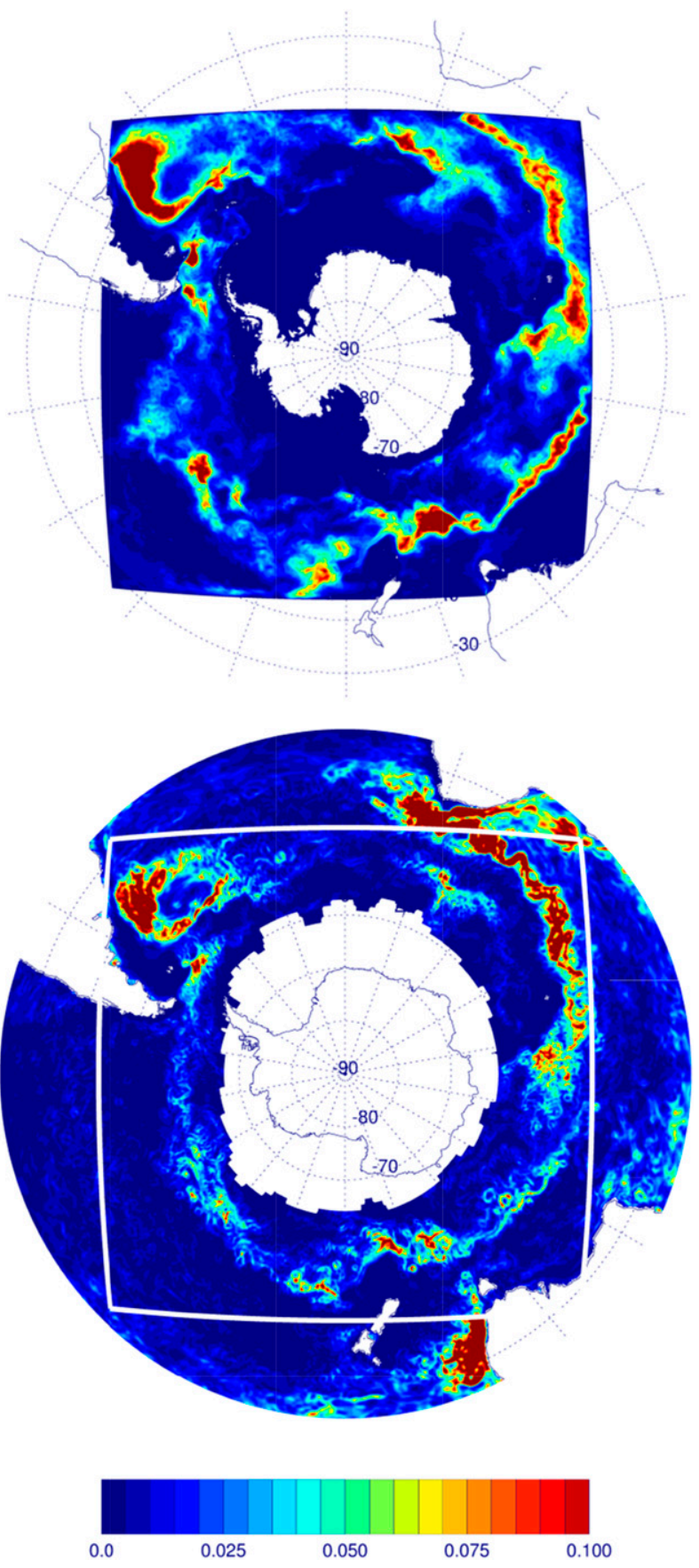

FIG. 2. (top) Model EKE $\left(\mathrm{m}^{2} \mathrm{~s}^{-2}\right)$ over the last 5 years of the ERA-Int simulation. (bottom) EKE computed from AVISO satellite altimetry estimates of geostrophic velocity anomalies for 2010. Note the lack of altimetry data because of sea ice cover close to Antarctica.

(standard deviation $=8 \mathrm{Gt} \mathrm{yr}^{-1}$ ) variability (likely because of the recycling of the atmospheric forcing every year) after the first few years (Fig. 7). The model total basal melt is low compared to observation-based estimates that range from 750 to $1450 \mathrm{Gt} \mathrm{yr}^{-1}$ (Table 2). The 


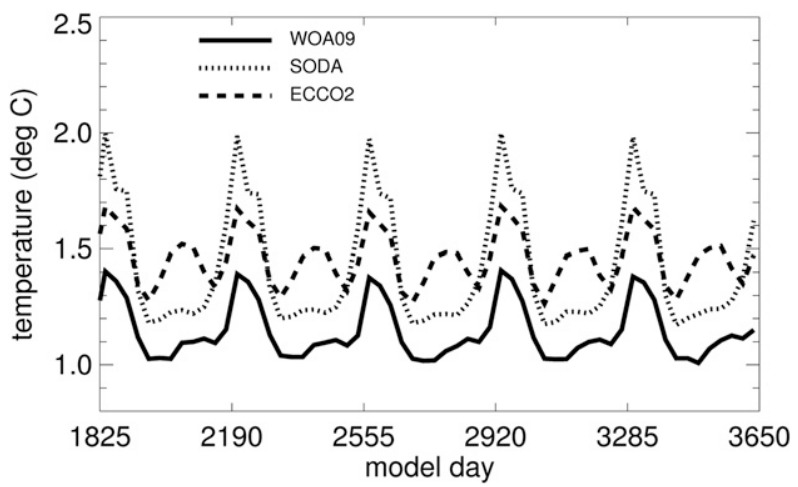

FIG. 3. Monthly RMSE $\left({ }^{\circ} \mathrm{C}\right)$ for the last 5 years over the entire model domain between the modeled (ERA-Int) SST and those from $W O A 09$, SODA, and ECCO2.

model value is closer to the model-based estimates of Hellmer (2004; $907 \mathrm{Gt} \mathrm{yr}^{-1}$ ) and Kusahara and Hasumi (2013; 770-944 $\mathrm{Gt} \mathrm{yr}^{-1}$ ) but considerably less than that of Timmermann et al. $\left(2012 ; 1600 \mathrm{Gt} \mathrm{yr}^{-1}\right)$. Note though that the Timmermann et al. (2012) model has much finer resolution under the ice shelves $(\sim 4 \mathrm{~km})$ than ours and much of their melt $\left(470 \mathrm{Gt} \mathrm{yr}^{-1}\right)$ comes from smaller shelves ( $20 \%$ of their total ice shelf area), many of which are not resolved in our domain.

Area-averaged model melt rates for the 10 larger ice shelves (same list as Timmermann et al. 2012) are reasonably close to observations (Table 2) for the largest ice shelves (Ross, Filchner-Ronne, and Amery) and other "cold" water shelves (Brunt and Riiser-Larsen, Fimbulisen and Jelbart, and Larsen C), but are significantly low for the "warm" water shelves along the Amundsen and Bellingshausen Seas (Abbot, George VI, Getz, and Pine Island).

\section{b. Differences between ERA-Interim and PWRF forcing}

The annual average difference in 10-m wind speeds between the PWRF simulation and ERA-Interim (Fig. 8) shows that PWRF winds are slightly weaker than ERA-Interim over much of the Southern Ocean but significantly stronger next to the coast of Antarctica where the terrain effects are better captured by the higher spatial resolution of PWRF; PWRF is simulating stronger circumpolar easterly winds (Parish and Bromwich 2007) adjacent to Antarctica, and it has been shown (Bromwich et al. 2013) that PWRF winds compare better to coastal observations with increased model resolution. A recent study (Sanz Rodrigo et al. 2013) showed ERAInterim $10-\mathrm{m}$ wind speeds to be $20 \%$ too low along the Antarctic coast. Monthly average differences in the wind speed (not shown) show that PWRF winds are weaker than ERA-Interim over sea ice in winter, meaning that

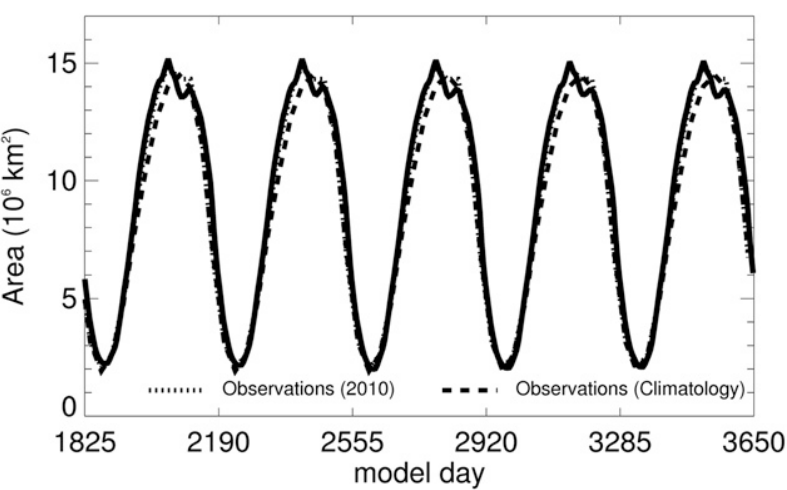

FIG. 4. Model (ERA-Int) total ice area (solid line) for the last 5 years compared with SSM/I observed ice area for just the year 2010 and climatology (1979-2012).

the likely cause of the slightly weaker PWRF winds over parts of the Southern Ocean is the surface drag specification over sea ice for each atmospheric model. The low-pressure trough surrounding Antarctic is at the same latitude in both atmospheric models (not shown) and there is no poleward or equatorward shifting of the mean winds.

ERA-Interim 2-m air temperatures along the coast have small biases versus station observations (Fig. 2 in Bracegirdle and Marshall 2012). The annual average difference in 2-m air temperatures (not shown) shows that PWRF is slightly warmer than ERA-Interim over most of the continental shelf. However, there is a strong seasonality to the differences, with PWRF being slightly warmer near the coast in spring, significantly warmer near the coast in fall, and noticeably colder in the summer (Fig. 9). There are fewer clouds over sea ice for PWRF than ERA-Interim and this leads to greater incident solar radiation in spring and fall, which is thought to be the cause of the warmer nearshore temperatures in spring and one of two causes in the fall. Also in fall, March is when the atmospheric temperatures begin to drop significantly over the continental shelf oceans and the most heat is lost from the water to the atmosphere before the sea ice covers the continental shelf. As both PWRF and ERA-Interim use the same ocean SST and sea ice extent, stronger PWRF winds near the coast in March (Fig. 8) lead to a greater exchange of heat from the ocean to the atmosphere during this time. The skin temperature over sea ice cannot be raised above the freezing point, thus limiting increases in peak "daytime" summer atmospheric temperatures due to increased insolation. Because the fewer clouds also allow more longwave radiation to be released from the surface during "nighttime," this leads to the summer temperatures (averaged over the entire day) being lower for PWRF. 
A)
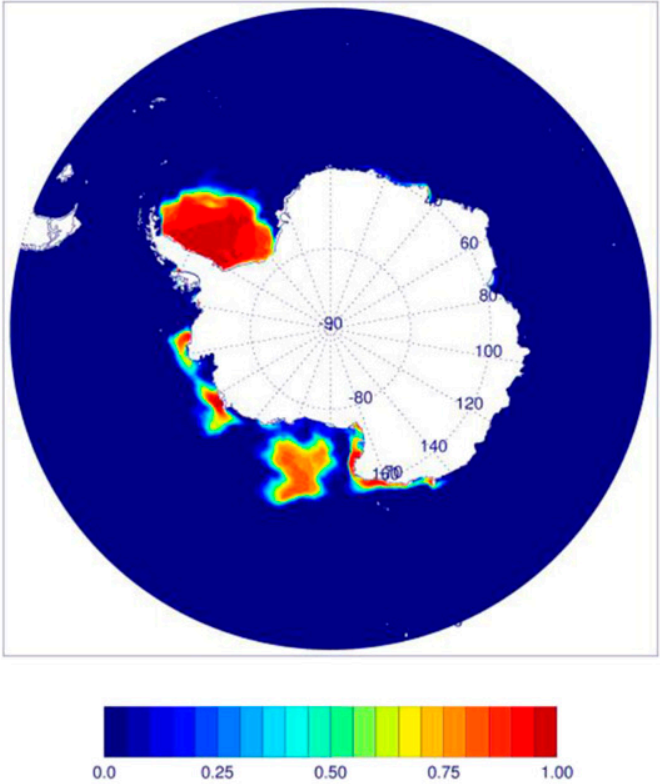

C)
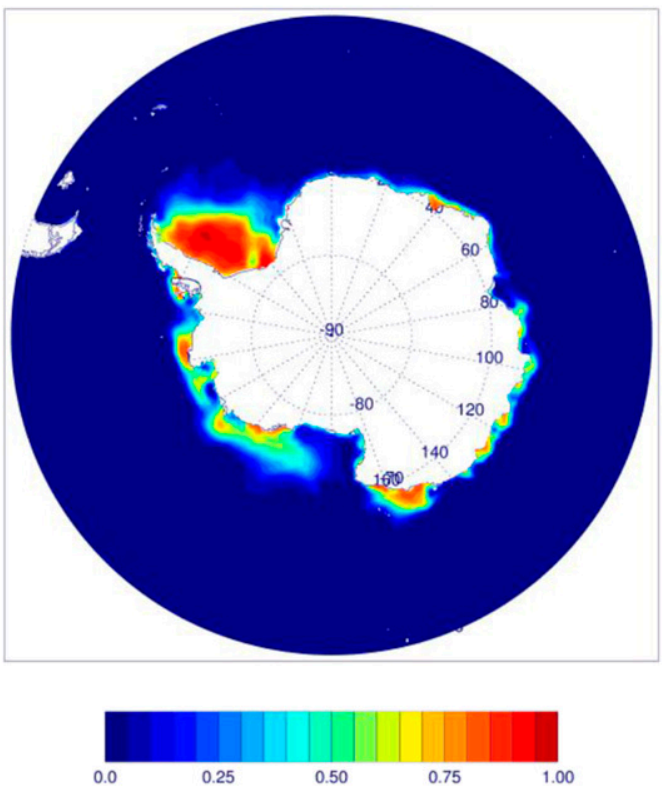

B)
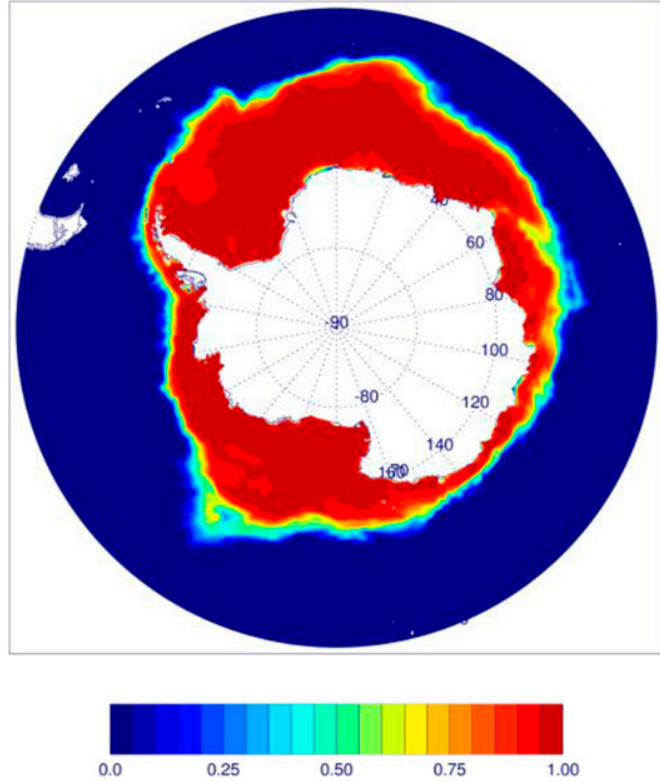

D)
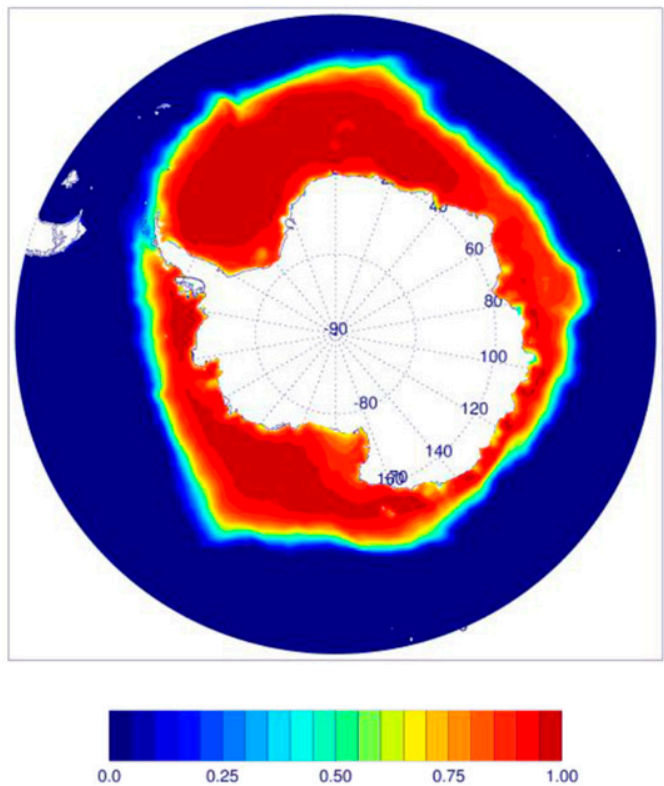

FIG. 5. (a),(b) Modeled (ERA-Int) and (c),(d) observed sea ice concentration for (left) February and (right) August.

c. Circum-Antarctic differences in the ice shelf basal melt

The total annual average ice shelf melt is increased by $14 \%\left(664-759 \mathrm{Gt} \mathrm{yr}^{-1}\right)$ when the 30-km PWRF winds are used in place of the $80-\mathrm{km}$ resolution ERA-Interim winds (Fig. 6). The increase is only $3 \%\left(664-686 \mathrm{Gt} \mathrm{yr}^{-1}\right)$ when both PWRF air temperatures and winds are used. As with the ERA-Int simulation, there is little interannual variability in the basal melt rate in both the PWRF (standard deviation $=5 \mathrm{Gt} \mathrm{yr}^{-1}$ ) and PWRF+ $\left(6 \mathrm{Gt} \mathrm{yr}^{-1}\right)$ cases. Most of the difference in the melt occurs during the peak melting in late summer/early fall, but the increased melting continues into the late fall. The 


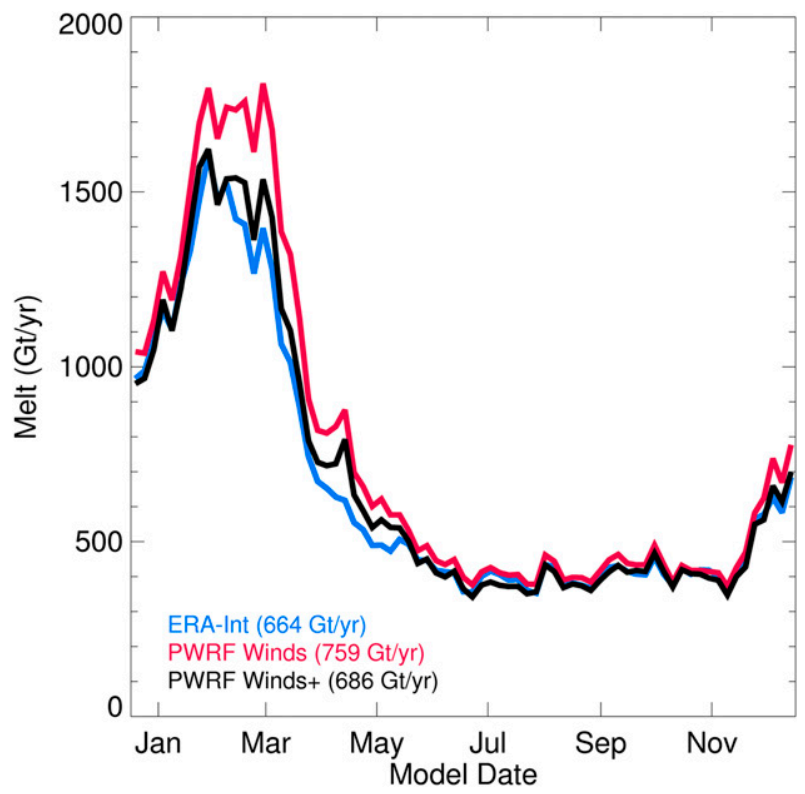

FIG. 6. Climatology over the last 5 years of the three model runs (Table 1) of the total model ice shelf basal melt $\left(\mathrm{Gt} \mathrm{yr}^{-1}\right)$.

peak summer melting occurs in February for the ERAInt case, a little later in February in the PWRF+ case, and into March for the PWRF case.

The heat budget for the water in the ice shelf cavities (Fig. 10) shows that the dominant processes are surface cooling and lateral advection of heat into the cavities. The surface cooling of the water/basal melt of the ice shelf peaks in February, but the heat flux into the ocean surface, which in the cavity is isolated from any direct contact with the atmosphere, is always negative (basal melt). The horizontal advection of heat into the ice shelf cavities also peaks in February and is positive (heat added to the cavity) or close to zero most of the year. When the winds are switched to PWRF winds, there is a small net increase in the heat advected underneath the ice shelves (Fig. 10), with the maximum increase occurring in March (explaining the shift from February to March of the peak basal melt) and a small decrease in the heat advection through much of the winter. The surface heat flux into the water is a little more negative (increased basal melt) throughout the year, but with most of the increased melting in summer and fall. The changes in the heat advection and surface flux are similar when the PWRF temperatures are used (PWRF+ case), but the increase in basal melting is reduced throughout the year while the increase in heat advection is reduced primarily in summer.

In both the PWRF and PWRF + cases, the change in the heat flux due to increased melt is a little greater than that necessary to balance the increased heat delivered to the ice shelf cavity by lateral advection. This is because, not only is more heat delivered to the cavities with the PWRF winds, but there is a stronger transfer of heat between the water and the ice shelf. The coefficients for the transfer of heat and salt between the base of the ice shelf and the waters underneath are functions of the friction velocity (Holland and Jenkins 1999). The PWRF winds are generally stronger in front of the ice shelves (Fig. 8), which leads to stronger exchange (and stronger coastal currents; see Fig. S2 in the online supplement) and thus greater velocities directly under the ice shelves (Fig. 11). The stronger exchange is not only directly wind driven (note that the difference in the friction velocities does not increase when the ice cover is reduced in summer), but also partially density driven because of different ice formation rates and resulting stratification directly in front of the ice shelves. These greater friction velocities lead to a slight increase in the transfer of heat from the ocean to the ice throughout the year, and the more efficient heat transfer leads to a slight reduction of the average water temperature in the cavity. There is very little difference in the average friction velocity between the PWRF+ and PWRF cases.

The heat advected into the ice shelf cavities comes from the Antarctic continental shelves. A heat budget for all the water over the Antarctic continental shelves (including the ice shelf cavities) shows (Fig. 12) that the dominant processes in the heat budget here are also surface heating and cooling and the lateral advection of heat. The surface heating is strongest in January and the strongest surface cooling is in early fall (March-April) just before the continental shelves become covered in ice and the shelf waters are insulated from the atmosphere. The horizontal advection of heat onto the continental shelves is almost always positive. PWRF winds cause a net increase in the heat advection onto the continental shelf and heat lost to the atmosphere compared to ERA-Interim winds, with most of the increased heat loss and much of the increased heat advection occurring in the fall. PWRF air temperatures reduce the net increase in on-shelf lateral heat transport and surface heat loss to the atmosphere. Note that the PWRF+ case also has smaller surface heating than the PWRF case during the peak summer melting months. In both the PWRF and PWRF+ cases, the net annual increase in heat lost to the atmosphere is greater than the increased heat transport onto the continental shelf.

Much of the (relatively) large increase in the heat lost to the atmosphere over the continental shelf for the PWRF and PWRF + cases in the fall can be tied to the sea ice conditions. The sea ice area over the continental shelf is, in the mean, very similar for all three simulations (not shown). However, when the sea ice starts to grow 
Total

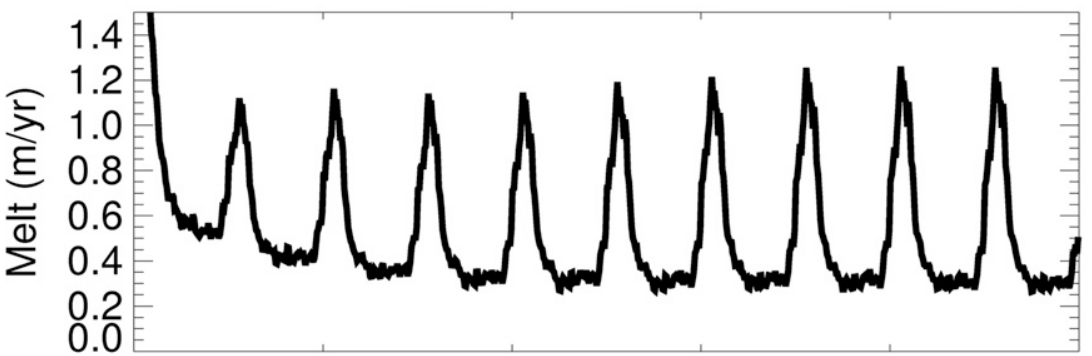

Cold Shelf
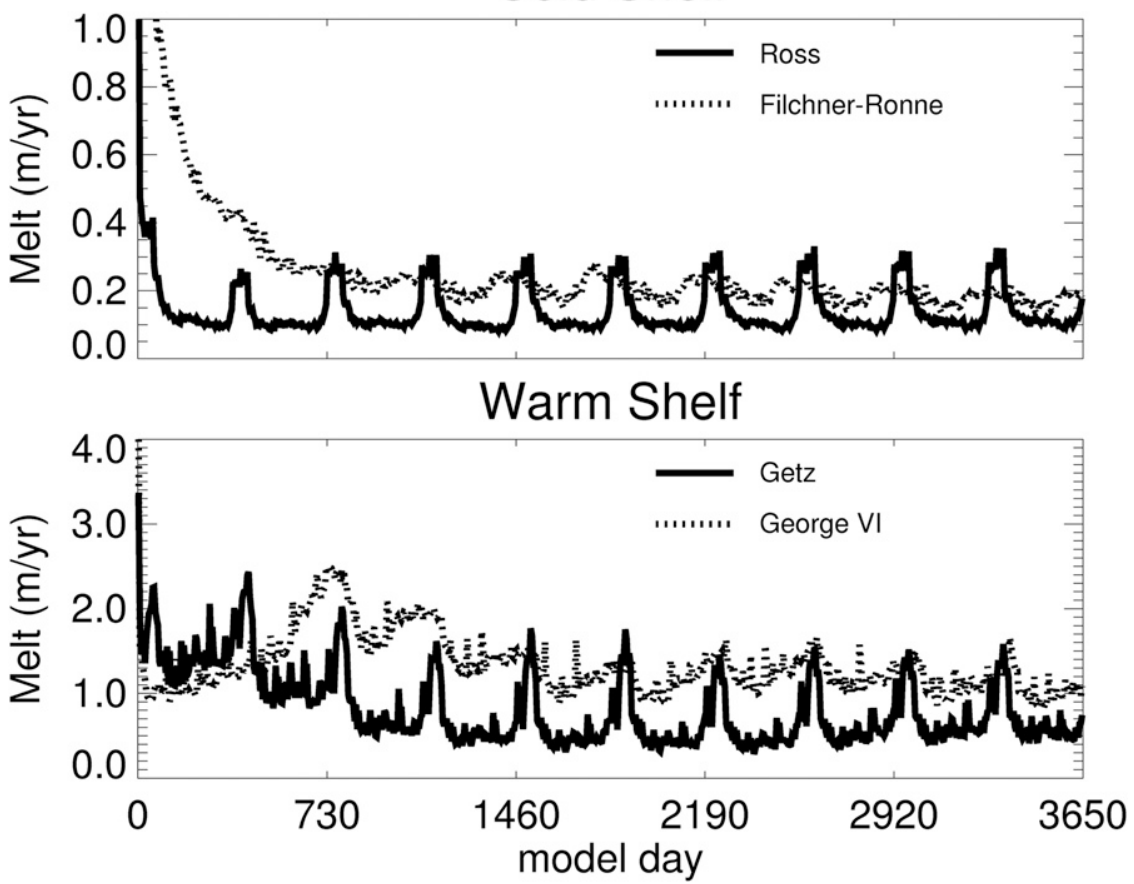

FIG. 7. Temporal evolution over the entire ERA-Int simulation of the average melt rate $\left(\mathrm{m} \mathrm{yr}^{-1}\right)$ of all the ice shelves and of specific examples of cold (Filchner-Ronne and Ross) and warm (George VI and Getz) water shelves.

back over the continental shelf in fall, the stronger nearshore PWRF winds (Fig. 8) push ice away from the coast in some locations, leading to a period (April, Fig. 13) of lower total ice area over the shelf that lasts until the ice grows enough to cover almost the entire shelf in all simulations. Maximum heat loss to the atmosphere occurs not when the atmosphere is coldest in winter, but in early fall (March-April, Fig. 12) before the area is covered by ice. There is a greater loss of heat to the atmosphere in April for the PWRF cases when the water is exposed to the cold air temperatures for a longer period than the ERA-Int case. The warmer PWRF+ temperatures over the continental shelves in early fall (not shown) further delay sea ice cover of the continental shelf waters. However, since the PWRF temperatures are warmer at this time than the ERA-Int case, the April increase in heat loss is similar to that for the PWRF case. The ice conditions are similar between PWRF and PWRF+ in summer when the PWRF+ coastal temperatures are cooler (Fig. 9), leading to the reduction in the summer heat gain for PWRF+ relative to PWRF.

\section{d. Regional differences in the ice shelf basal melt}

The results in the previous section are averages over the entire Antarctic continental shelf. However, the effect of different atmospheric forcing can be quite spatially heterogeneous. In the Ross Ice Shelf (RIS) cavity, the dominant processes in the heat budget (not shown) 
TABLE 2. Comparison of modeled basal melt to observation-based estimates for the entire continent and the larger Antarctic ice shelves. The range in the modeled estimates is the standard deviation of the 5-day averages and mostly represents the seasonal variability.

\begin{tabular}{|c|c|c|}
\hline Ice shelf & Modeled basal melt & Observation-based estimate \\
\hline Total & $664 \mathrm{Gt} \mathrm{yr}^{-1}$ & $\begin{array}{l}756 \mathrm{Gt} \mathrm{yr}^{-1}\left(\mathrm{Jacobs}^{-1} \text { et al. 1996) }\right. \\
1027 \mathrm{Gt} \mathrm{yr}^{-1}\left(\mathrm{Rignot}^{-1} \text { and Jacobs } 2008\right) \\
1280-1628 \mathrm{Gt} \mathrm{yr}^{-1} \text { (Depoorter et al. 2013) } \\
1090-1560 \mathrm{Gt} \mathrm{yr}^{-1} \text { (Rignot et al. 2013) }\end{array}$ \\
\hline Amery & $1.10 \pm 0.54 \mathrm{~m} \mathrm{yr}^{-1}$ & $\begin{array}{l}0.71-0.97 \mathrm{~m} \mathrm{yr}^{-1} \text { (Wen et al. 2010) } \\
0.36-0.62 \mathrm{~m} \mathrm{yr}^{-1} \text { (Yu et al. 2010) } \\
0.30-1.00 \mathrm{~m} \mathrm{yr}^{-1} \text { (Depoorter et al. 2013) } \\
0.2-1.0 \mathrm{~m} \mathrm{yr}^{-1} \text { (Rignot et al. 2013) }\end{array}$ \\
\hline Ross & $0.14 \pm 0.06 \mathrm{~m} \mathrm{yr}^{-1}$ & 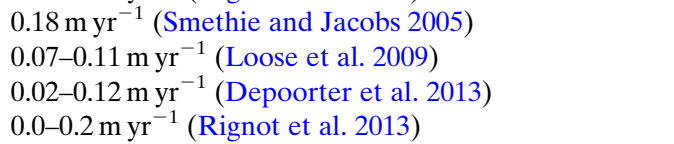 \\
\hline Getz & $0.66 \pm 0.30 \mathrm{~m} \mathrm{yr}^{-1}$ & $\begin{array}{l}\text { 1.1-4.6 } \mathrm{m} \mathrm{yr}^{-1} \text { (Jacobs et al. 2013) } \\
\text { 3.5-4.7 m yr} \text { (Depoorter et al. 2013) }^{-1} \text { (D.9-4.7 } \mathrm{m} \mathrm{yr}^{-1} \text { (Rignot et al. 2013) }\end{array}$ \\
\hline Pine Island & $1.62 \pm 0.97 \mathrm{~m} \mathrm{yr}^{-1}$ & $\begin{array}{l}20-28 \mathrm{~m} \mathrm{yr}^{-1} \text { (Rignot 1998) } \\
22-33 \mathrm{~m} \mathrm{yr}^{-1} \text { (Jacobs et al. 2011) } \\
\text { 13.6-18.2 (Depoorter et al. 2013) } \\
\text { 15.2-17.2 (Rignot et al. 2013) }\end{array}$ \\
\hline Abbot & $0.34 \pm 0.18 \mathrm{~m} \mathrm{yr}^{-1}$ & $\begin{array}{l}\text { 2.4-3.1 (Depoorter et al. 2013) } \\
1.1-2.3 \text { (Rignot et al. 2013) }\end{array}$ \\
\hline George VI & $1.19 \pm 0.18 \mathrm{~m} \mathrm{yr}^{-1}$ & $\begin{array}{l}2.1 \mathrm{~m} \mathrm{yr}^{-1} \text { (Potter and Paren 1985) } \\
2.8 \mathrm{~m} \mathrm{yr}^{-1} \text { (Corr et al. 2002) } \text { 3.1-4.8 } \mathrm{yr}^{-1} \text { (Jenkins and Jacobs 2008) } \\
\text { 2.6-3.2 (Depoorter et al. 2013) } \\
\text { 3.1-4.5 (Rignot et al. 2013) }\end{array}$ \\
\hline Larsen C & $0.35 \pm 0.14 \mathrm{~m} \mathrm{yr}^{-1}$ & $\begin{array}{l}0.16-0.44 \mathrm{~m} \mathrm{yr}^{-1} \text { (Depoorter et al. 2013) } \\
-0.6 \text { (mass gain) to } 1.4 \text { (mass loss) (Rignot et al. 2013) }\end{array}$ \\
\hline Filchner-Ronne & $0.19 \pm 0.02 \mathrm{~m} \mathrm{yr}^{-1}$ & $\begin{array}{l}0.24-0.44 \mathrm{~m} \mathrm{yr}^{-1} \text { (Nicholls et al. 2003) } \\
0.20-0.34 \mathrm{~m} \mathrm{yr}^{-1} \text { (Nicholls et al. 2009) } \\
0.03-0.21 \mathrm{~m} \mathrm{yr}^{-1} \text { (Depoorter et al. 2013) } \\
0.2-0.4 \text { (Rignot et al. 2013) }^{\text {(Rigno }}\end{array}$ \\
\hline Brunt + Riiser-Larsen & $0.67 \pm 0.43 \mathrm{~m} \mathrm{yr}^{-1}$ & $\begin{array}{l}0.13-0.53 \text { (Depoorter et al. 2013) } \\
-0.1 \text { (mass gain) to } 0.3 \text { (mass loss) (Rignot et al. 2013) }\end{array}$ \\
\hline Fimbulisen + Jelbart & $1.51 \pm 1.13 \mathrm{~m} \mathrm{yr}^{-1}$ & $\begin{array}{l}0.25-0.79 \mathrm{~m} \mathrm{yr}^{-1} \text { (Depoorter et al. 2013) } \\
0.2-0.7 \mathrm{~m} \mathrm{yr}^{-1} \text { (Rignot et al. 2013) } \\
1 \mathrm{~m} \mathrm{yr}^{-1} \text { (Langley et al. 2014) }\end{array}$ \\
\hline
\end{tabular}

are once again the surface cooling and lateral advection of heat into the cavity. The PWRF case has a small net increase in the heat advected underneath the RIS compared to the ERA-Int case. The surface heat flux becomes a little more negative (increased melting) throughout most of the year, with the largest increase in the basal melt during late summer. Including the PWRF temperatures slightly reduces the difference in the surface flux from the ERA-Int case, but both the heat advection and surface flux are similar to the PWRF case. However, the heat balance over the open (not underneath the RIS) portion of the Ross Sea continental shelf (Fig. 14) differs from the circumAntarctic case. There is a smaller horizontal advection of heat throughout the year onto the Ross Sea shelf for the PWRF and PWRF+ cases compared to the base case and less surface winter cooling and less summer heating (net effect is a lower heat loss to the atmosphere). Note that the relative loss of advective heat is greater than the net increase in heat at the surface, leading to a lower mean temperature over the Ross Sea continental shelf for these two cases compared to ERA-Int.

The mean winds over the Ross Sea are southerlies (Parish et al. 2006), and regional model simulations suggest that a strengthening of these southerlies will increase the on-shelf transport of relatively warm CDW in the Ross Sea (Smith et al. 2014). These southerlies also result in areas of reduced sea ice concentration throughout the winter (polynyas) along the RIS (Morales Maqueda et al. 2004). PWRF winds over the Ross Sea (Fig. 8) are stronger immediately adjacent to the western RIS front, significantly stronger along the Victoria Land coast, and weaker over the central shelf and the shelf break. The stronger winds near the ice shelf front lead to a stronger volume exchange into/out of the ice shelf cavity and larger friction 

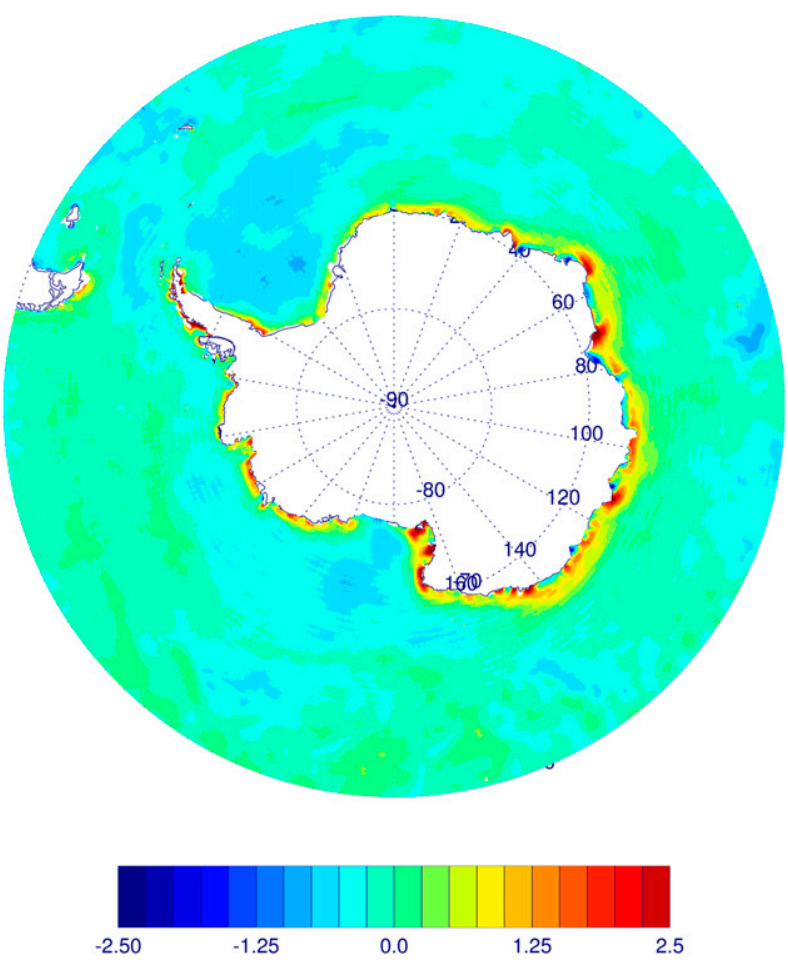

FIG. 8. Mean of the difference (computed every $6 \mathrm{~h}$ ) of $10-\mathrm{m}$ wind speed $\left(\mathrm{m} \mathrm{s}^{-1}\right)$ over the year 2010 between 30-km PWRF winds and ERA-Interim winds (positive values mean stronger PWRF winds).

velocities under the shelf [11\% (9\%) increase for PWRF $(\mathrm{PWRF}+)]$, thus explaining the increases in the heat advection into the cavity and the melting underneath the ice shelf. Meanwhile, the weaker southerlies over the shelf break reduce the advection of warm CDW onto the continental shelf. The weaker southerlies over the central part of the continental shelf also reduce the advection of sea ice away from the RIS front, thus reducing the extent of the wintertime low ice concentration area along the ice shelf (i.e., slightly more ice over the continental shelf in winter; Fig. 13), which decreases the wintertime loss of heat to the atmosphere (Fig. 14).

The basal melt rate and mean temperature over the continental shelf for the Amundsen Sea sector of the model take a little more than 5 years to approach a steady state, so the results shown for the Amundsen region are from the last 3 years of the simulation. The heat budget for the ice shelf cavities in the Amundsen Sea (not shown) has an ocean surface flux that is always negative (basal melting) with a peak in March and a somewhat variable lateral advection term that is generally positive with maximum transport of heat in January-March. PWRF winds lead to a small net increase in the heat advected underneath the ice shelves but no net change in the surface flux. Including the PWRF temperatures leads to a
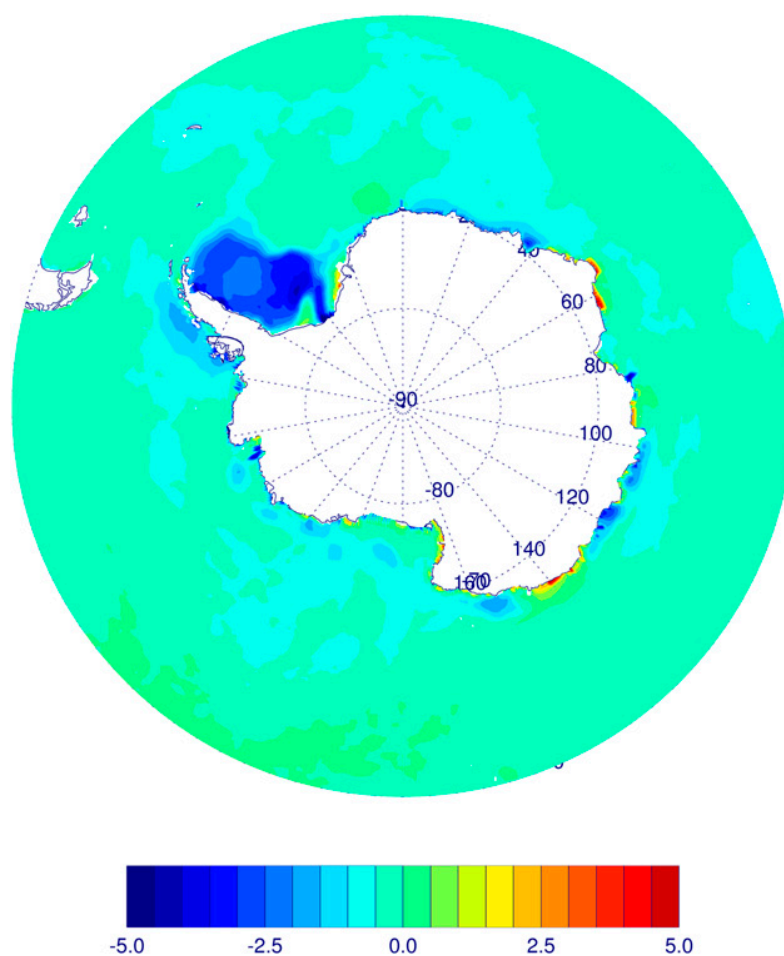

FIG. 9. Mean of the difference (computed every $12 \mathrm{~h}$ ) of 2-m air temperature $\left({ }^{\circ} \mathrm{C}\right)$ for the month of February between $30-\mathrm{km}$ PWRF temperatures and ERA-Interim temperatures (positive values mean warmer PWRF temperatures).

very small increase in the heat advected into the cavity and the basal melting of the ice shelves. The open Amundsen Sea continental shelf heat budget (Fig. 15) shows that, opposite of what happens on the Ross Sea continental shelf, there is a larger horizontal advection of heat throughout most of the year for the PWRF and PWRF+ cases and, other than a brief period in late March, there is more heat lost through the ocean surface.

The mean depth-averaged temperatures on the Amundsen Sea continental shelf are too cold in all three model runs (Table 3), with the simulations using PWRF winds being colder than those using ERA-Interim winds (Fig. S3 in the online supplement). There is less sea ice in March over the continental shelf for the ERA-Interim simulation (not shown), which explains the greater loss of heat to the atmosphere in March compared to PWRF and PWRF+ (Fig. 15), but the sea ice area is similar in all three simulations the rest of the year. However, the stronger PWRF winds over the inner continental shelf (Fig. 8) lead to more local ice formation every year (Fig. 16), which explains the increased loss of heat at the surface for most of the year in the PWRF and PWRF+ cases.

Winds over the Amundsen Sea shelf break are thought to modulate transport of warm CDW onto the continental shelf, with stronger westerly winds leading to 
Heat Budget (Ice Shelf Cavities)
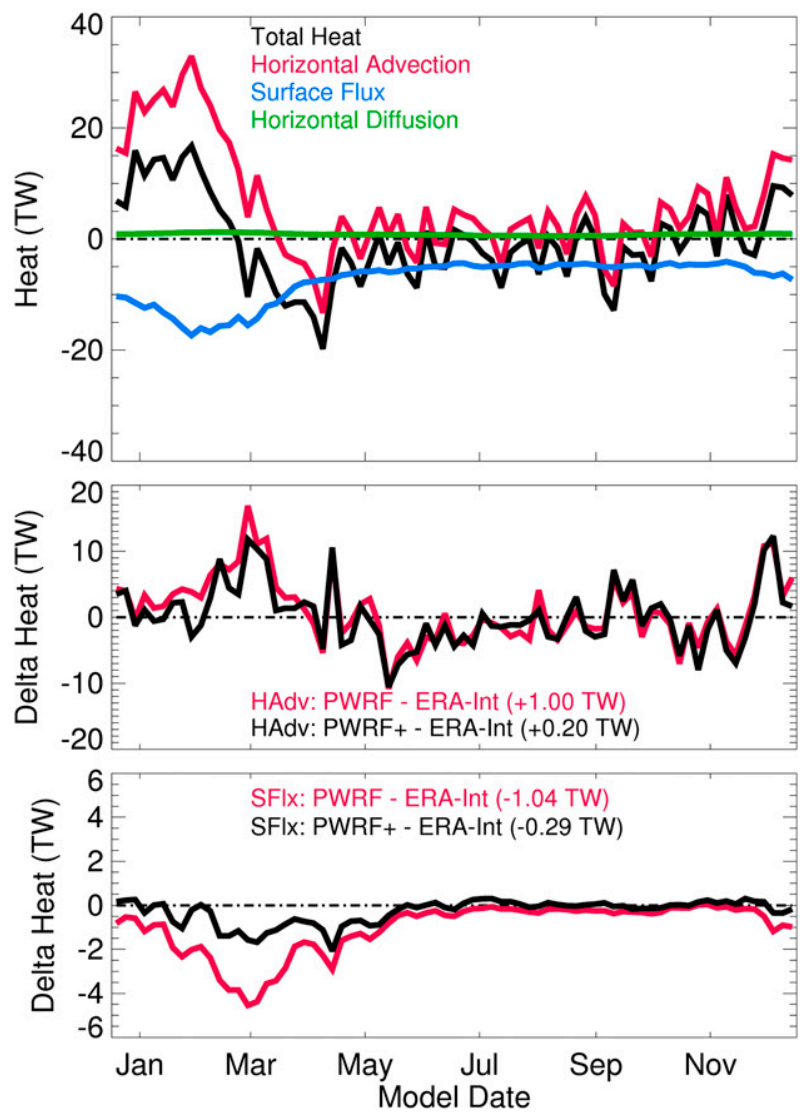

FIG. 10. (top) Climatology of the terms in the heat flux budget for the entire volume of water underneath all ice shelves for the ERAInt simulation. (middle) Difference in the lateral advection of heat into the ice shelf cavities for the PWRF and PWRF+ runs vs ERAInt. (bottom) Difference in the surface heating (basal melt) of the water in the ice shelf cavities for the PWRF and PWRF+ runs vs ERA-Int.

greater CDW transport (Thoma et al. 2008; Carvajal et al. 2013; Wåhlin et al. 2013). The mean ERA-Interim winds near the coast are easterlies and the winds over the shelf break vary seasonally, but are on average weakly easterly. The PWRF winds are stronger near the coast and weaker over the shelf break, but the PWRF westerly wind component is weaker everywhere over the Amundsen Sea (not shown). This should lead to decreased lateral heat advection with the PWRF winds, opposite of what is observed with the model, if the advection just depended on the on-shelf transport. However, the advection of any quantity depends on the velocity and the spatial gradient of the quantity. The modeled temperatures over the continental slope (defined by the 1000- and 3500-m isobaths) are much closer to observations than the shelf temperatures for all three simulations (Table 3). While the PWRF and PWRF+

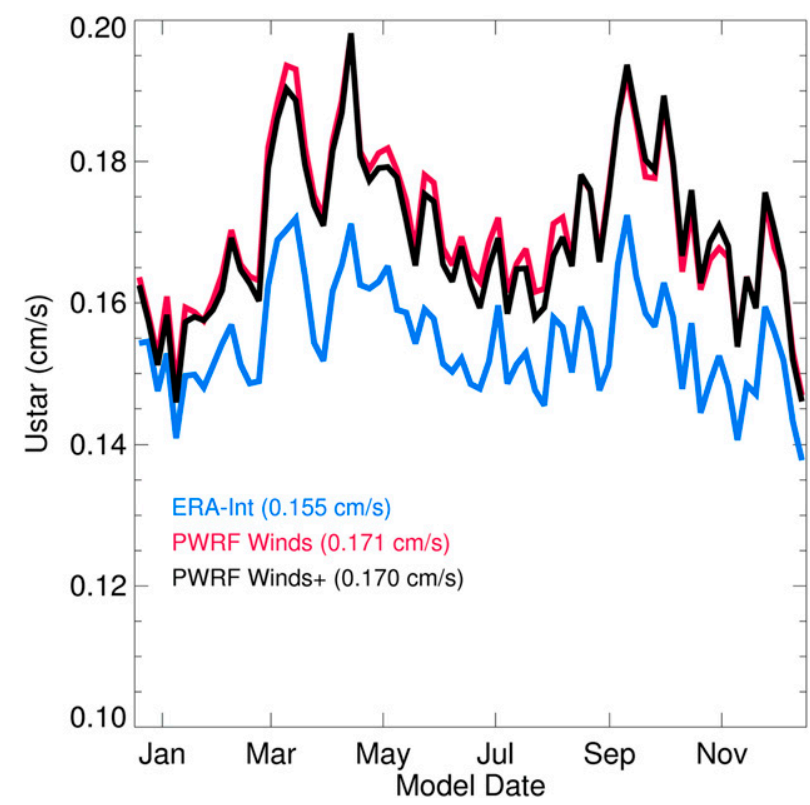

FIG. 11. Climatology of the mean friction velocity $\left(u^{*}\right)$ in the model layer just below the ice shelves for all three simulations.

temperatures are lower over the continental slope than ERA-Int, they are closer to ERA-Int than over the shelf. This leads to a greater cross-shelf break gradient in temperature for the PWRF and PWRF+ cases. The heat advection onto the continental shelf is greater for the PWRF winds, not necessarily because the winds induce more transport of warm water onto the shelf, but because the winds lead to a greater surface cooling (bottom part of Fig. 15) of the shelf waters.

There is an approximately equivalent transport of heat into the ice shelf cavities for all three simulations. The temperatures in the ice shelf cavities in the PWRF and PWRF+ cases are slightly lower than ERA-Int (Table 3), but the exchange coefficients are greater (14\% increase in mean friction velocity for both PWRF and PWRF+), which results in approximately equal surface heat flux underneath the ice shelves.

\section{Discussion}

The most rapid observed thinning of Antarctic ice shelves occurs along the Amundsen and Bellingshausen Sea coasts (Pritchard et al. 2012) because these shelves are "warm water" shelves where much of the heat of the intruding $\mathrm{CDW}$ is not mixed out of the deeper shelf waters and deep temperatures can be over $1^{\circ} \mathrm{C}$. However, much of this warm water is eroded on the Amundsen Sea continental shelf in all three simulations (Table 3). A cold Amundsen Sea continental shelf is a common problem in Southern Ocean models, including other similarly scaled 
Heat Budget (Continental Shelf)
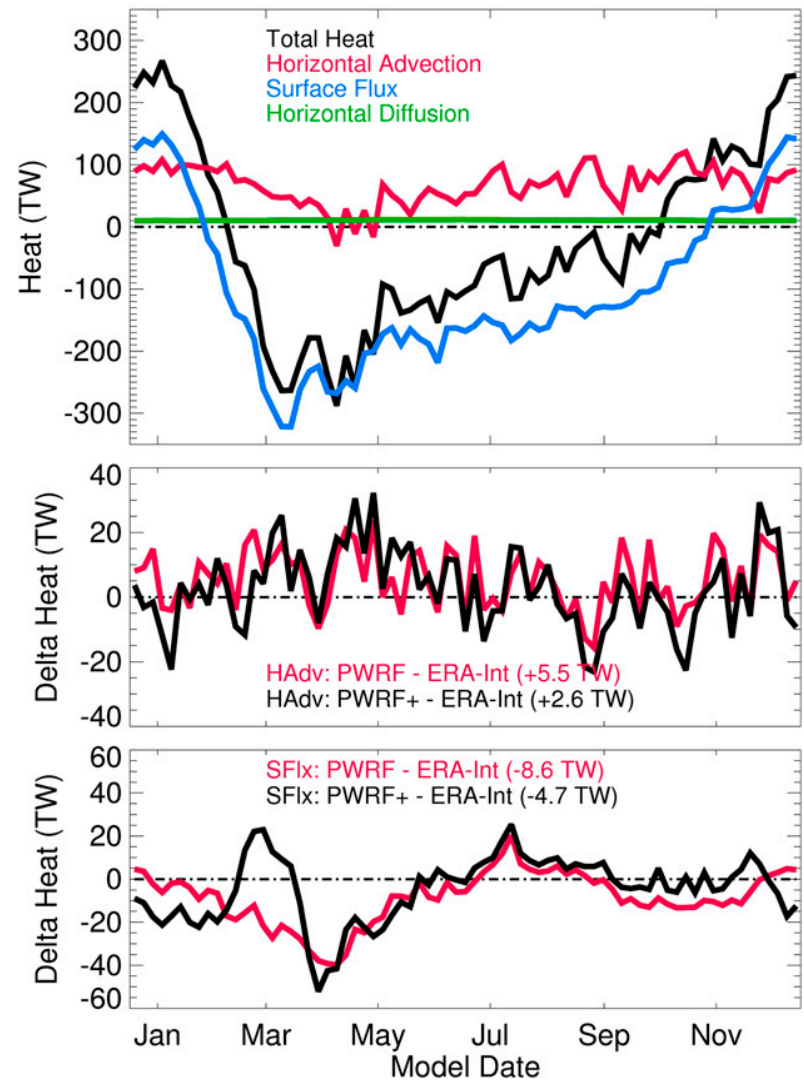

FIG. 12. (top) Climatology of the terms in the heat flux budget for the entire volume of water on the Antarctic continental shelves (including ice shelf cavities) for the ERA-Int simulation. (middle) Difference in the lateral advection of heat onto the continental shelf for the PWRF and PWRF+ runs vs ERA-Int. (bottom) Difference in the surface heating over the continental shelf for the PWRF and PWRF+ runs vs ERA-Int.

(resolution of $10-20 \mathrm{~km}$ on the continental shelf) circum-Antarctic models (Timmermann et al. 2012; Kusahara and Hasumi 2013). Kusahara and Hasumi (2013) felt that the 20-km resolution on the Amundsen shelf in their model "can not sufficiently resolve key topography that guides the CDW into" the inner continental shelf. Timmermann et al. (2012), with a finite element mesh having $10-\mathrm{km}$ spacing at the Antarctic coast and 4-km spacing underneath the Amundsen ice shelves, blamed a cold bias in the winter air temperatures used (NCEP reanalysis) leading to spuriously high sea ice formation resulting in deep convection and erosion of the deep temperature maximum, although they now believe (Nakayama et al. 2014) that the ocean grid resolution is more important than the air temperatures. Some regional models (Schodlok et al. 2012; Assmann et al. 2013) have no problem maintaining warm water on the Amundsen Sea continental shelf, although it is still
Delta Ice Area

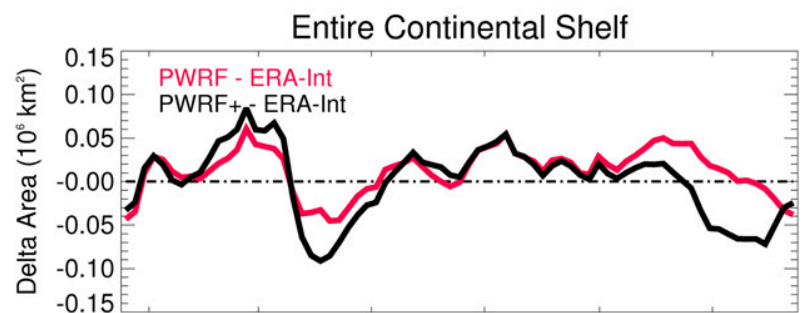

Ross Sea

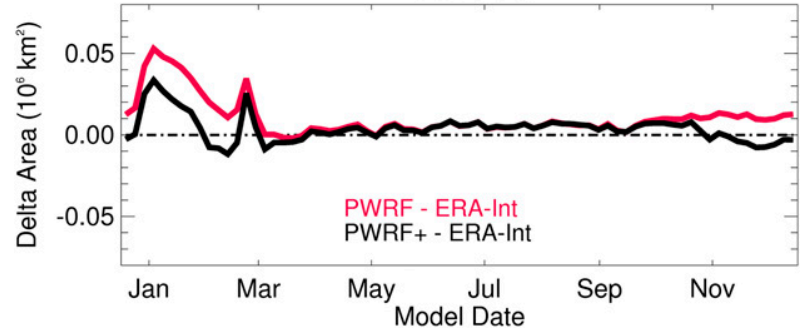

FIG. 13. (top) Climatology of the difference in the sea ice area over just the continental shelves for the PWRF and PWRF+ runs vs ERA-Int. (bottom) Climatology of the difference in the sea ice area over the Ross Sea continental shelf for the PWRF and PWRF+ runs vs ERA-Int.

an open question as to whether that is because of the better resolution $[1 \mathrm{~km}$ in the case of Schodlok et al. (2012)] or the regional temperatures being more constrained by the closer lateral boundaries.

It is difficult to tell from our results whether the too cold Amundsen shelf water in our model is due to too vigorous vertical mixing of heat out of the ocean, too weak lateral advection of heat onto the continental shelf, or some combination of both. The year chosen for the forcing (2010) could have contributed to the cold shelf temperatures in this region as it was an anomalous year with larger than typical Pine Island and Amundsen polynyas that stayed open longer than usual (Arrigo et al. 2012). This could have led to increased heat loss, sea ice formation, and vertical mixing on the Amundsen shelf resulting in anomalously cold deeper water that year. A test simulation forced by ERA-Int with the KPP boundary layer depth artificially reduced did increase the mean Amundsen continental shelf temperature by about $0.5^{\circ} \mathrm{C}$, which brings it much closer to observations (Table 3). However, this simulation had many unrealistic features. Finally, the idealized, high-resolution model of St-Laurent et al. (2013), which was set up to be a "warm water" AmundsenBellingshausen-type continental shelf, strongly implies that $10-\mathrm{km}$ model resolution will underestimate the transport of heat onto the continental shelf because of poorly represented baroclinic eddies.

Besides having a cold Amundsen shelf water, the model is on the low end of the most current estimates of 

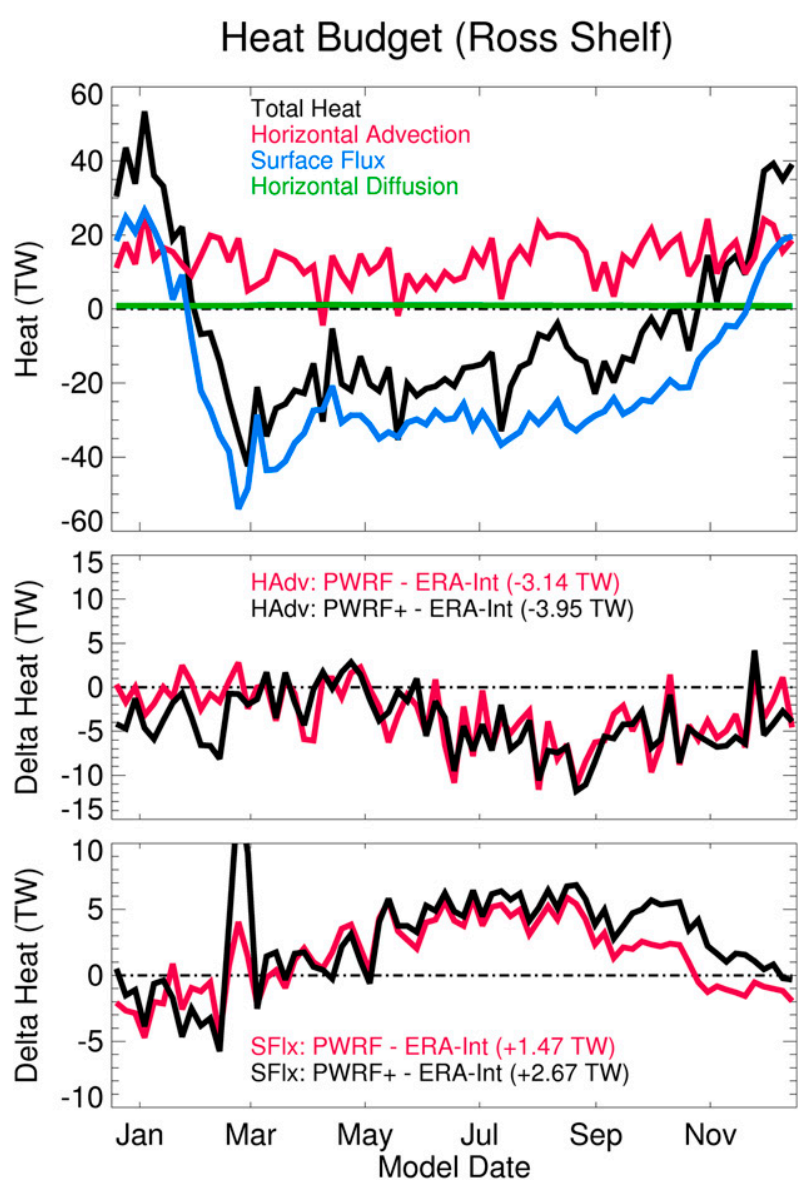

FIG. 14. (top) Climatology of the terms in the heat flux budget for the entire volume of water on the portion of the Ross Sea continental shelf not underneath an ice shelf for the ERA-Int simulation. (middle) Difference in the lateral advection of heat onto the continental shelf for the PWRF and PWRF+ runs vs ERA-Int. (bottom) Difference in the surface heating over the continental shelf for the PWRF and PWRF+ runs vs ERA-Int.

the total Antarctic ice shelf basal melt. Even though the ice shelves along the Amundsen Sea have been shown to be a major contributor to the total ice shelf melt (33\%; Depoorter et al. 2013), increasing the temperature to more realistic values on the Amundsen shelf only increased the total ice shelf basal melt by $\sim 6 \%$ (although, again, there were other less realistic aspects of this simulation). One possible cause of the low basal melt may be the model resolution. Not only will a $10-\mathrm{km}$ resolution model likely underestimate the transport of heat onto the continental shelf in some locations, it may also underestimate the transport of heat from the continental shelf into the ice shelf cavities. Årthun et al. (2013) showed that on a "cold" water shelf, eddy-driven transport of HSSW into an ice shelf cavity is reduced by as much as $50 \%$ if the model grid spacing no longer properly resolves the eddies on the continental shelf
Heat Budget (Amundsen Shelf)
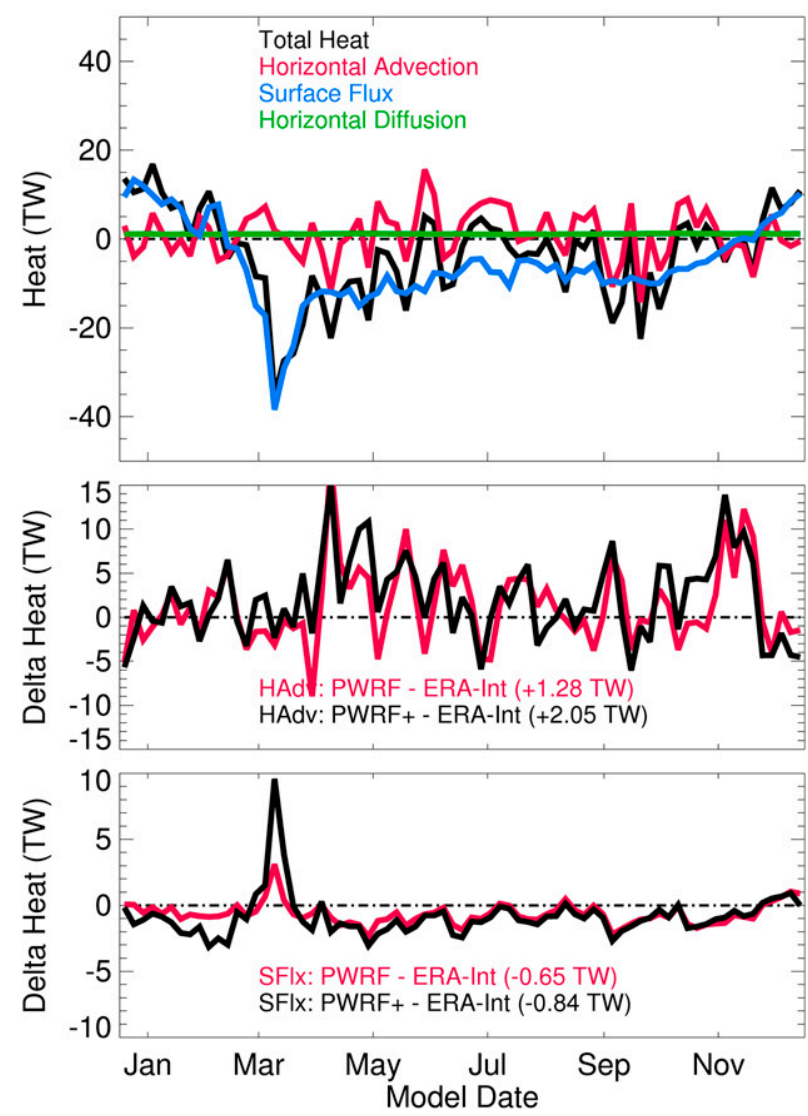

FIG. 15. (top) Climatology of the terms in the heat flux budget for the entire volume of water on the portion of the Amundsen Sea continental shelf not underneath an ice shelf for the ERA-Int simulation. (middle) Difference in the lateral advection of heat onto the continental shelf for the PWRF and PWRF+ runs vs ERA-Int. (bottom) Difference in the surface heating over the continental shelf for the PWRF and PWRF+ runs vs ERA-Int.

(from $500 \mathrm{~m}$ to $2-5 \mathrm{~km}$ in their case). The lack of tides in the model may also contribute to insufficient basal melt. Including tides in regional models of some cold water ice shelves such as the Filchner-Ronne (Makinson et al. 2011) or Larsen C (Mueller et al. 2012) doubles the melt rate. While the tidal contribution to basal melting may be smaller for other cold water ice shelves such as the Ross ( 25\%; Arzeno et al. 2014) and much smaller for warm water ice shelves [although that is still an open question, see Robertson (2013) and the discussion in Mueller et al. (2012)], the lack of tides is still likely to lead to an underestimate of the total Antarctic basal melt.

Finally, the results here show how important it is to properly represent ocean-atmosphere-sea ice interactions over the open continental shelves when trying to simulate the basal melting of the floating ice shelves. The large differences in the basal melt rate among all 
TABLE 3. Depth-averaged Amundsen Sea temperatures $\left({ }^{\circ} \mathrm{C}\right)$ for January-March. The comparison was done over January-March because they are the only months with a significant number of observations in WOA09 (although the model values do not change much when computed over the entire year).

\begin{tabular}{lccccc}
\hline \hline $\begin{array}{c}\text { Simulation/ } \\
\text { dataset }\end{array}$ & $\begin{array}{c}\text { Cont. } \\
\text { slope }\end{array}$ & $\begin{array}{c}\text { Cont. } \\
\text { shelf }\end{array}$ & $\begin{array}{c}\text { Slope/shelf } \\
\text { difference }\end{array}$ & $\begin{array}{c}\text { Ice } \\
\text { cavities }\end{array}$ & $\begin{array}{c}\text { Shelf/cavity } \\
\text { difference }\end{array}$ \\
\hline ERA-Int & 0.702 & -1.274 & 1.976 & -1.744 & 0.470 \\
PWRF & 0.619 & -1.456 & 2.075 & -1.826 & 0.370 \\
PWRF+ & 0.610 & -1.462 & 2.072 & -1.818 & 0.356 \\
WOA09 & 0.536 & -0.767 & 1.303 & N/A & N/A \\
\hline
\end{tabular}

three simulations in March and April (Fig. 6) when the continental shelves are losing the most heat to the atmosphere before they become sea ice covered indicate the importance of the atmospheric forcing near the coast. The differences in the fall atmospheric temperatures over the continental shelves between ERA-Interim and PWRF, and the effect this has on the ice shelf basal melt, implies that coupling the atmosphere to the ocean at high resolution is important to these processes. Part of the reason the higher-resolution atmosphere has warmer temperatures over the continental shelves in fall is because the stronger winds are blowing over a fixed ocean SST and fixed coastal open ocean areas, which leads to more exchange from the ocean. However, if PWRF were coupled to an ocean-sea ice model, the fall sea ice extent could be significantly different near the coast (as it was for the ocean stand-alone model here; Fig. 13), which would feed a different heat flux back into the atmosphere, possibly resulting in significant differences in the coastal atmosphere from the stand-alone version. We plan to examine these questions with our ACCIMA coupled model.

\section{Summary}

Iceberg calving and basal melt are the two important ways that glacial ice is lost from the Antarctic ice shelves. Basal melt of the ice shelves is dependent on transport of heat by oceanic flow underneath the ice shelf. The resulting basal melt is due to the relative size of oceanic heat transport across the shelf break, ocean surface heat flux over the open continental shelf, and transport of heat to the base of the floating ice shelf. We use a $10-\mathrm{km}$ horizontal grid spacing ocean model applied to the entire Southern Ocean to analyze the effect of atmospheric forcing resolution on the balance of these processes. Atmospheric forcing comes primarily from the ERA-Interim reanalysis (80-km resolution) as well as a polar WRF simulation (30-km resolution) that is forced by ERA-Interim.

The basic ocean simulation forced by ERA-Interim for 10 years is realistic compared to observed Drake Passage transport, EKE, SST, sea ice extent, and water
Amundsen Sea Ocean/lce Mass Flux

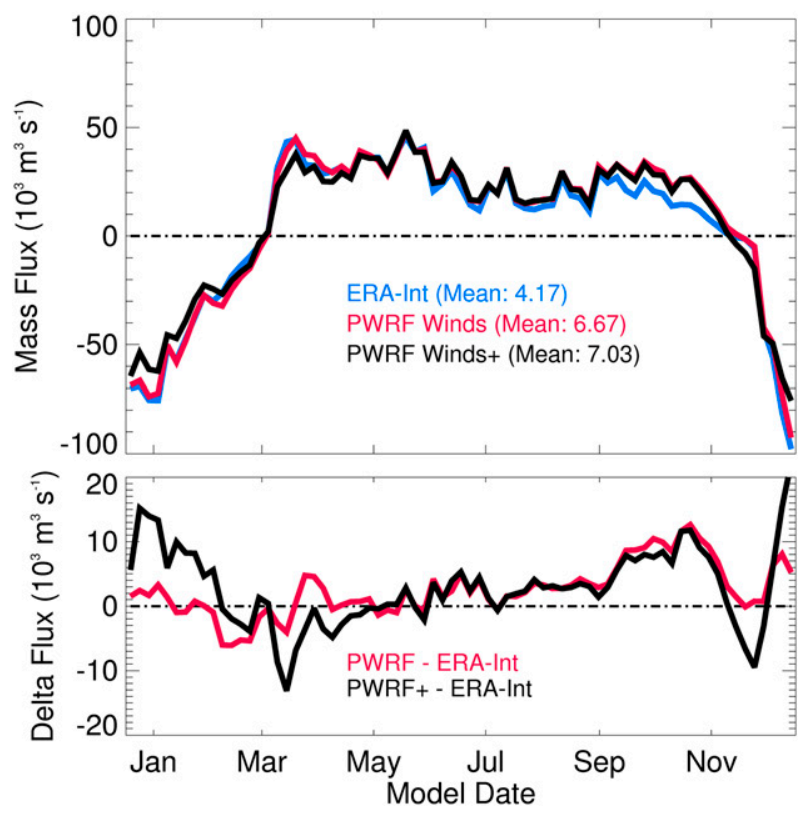

FIG. 16. (top) Climatology of the total mass flux $\left(\mathrm{m}^{3} \mathrm{~s}^{-1}\right)$, including frazil ice production, between the ocean and sea ice on the Amundsen Sea continental shelf for each simulation (positive values indicate ice production). (bottom) Difference in the oceanice mass flux for the PWRF and PWRF runs vs ERA-Int.

mass transformation. The drift in the model state is small over the last 5 years, although there are strong seasonal cycles in many model variables. Total basal melt of all ice shelves in the model is somewhat below estimates of basal melt over all Antarctic ice shelves.

The PWRF simulations have stronger winds along the Antarctic coast because of a better representation of coastal land elevations. Using just the higher-resolution winds results in higher basal melt (14\% increase) because of more heat being delivered to the ice shelf cavities from the adjacent ocean and an increase in the efficiency of heat transfer between the water and the ice. The higherresolution winds also lead to changes in the heat delivered from the ocean to the continental shelves as well as changes in the heat lost to the atmosphere over the shelves. PWRF air temperatures are cooler in summer than ERAInterim, which reduces the net heat delivered to the ice shelves by reducing the surface heating in the summer. It is unclear how the atmospheric resolution affects the summer temperature change. Regional differences illustrate the interplay of processes resulting in basal melt.

Although there are unrealistic aspects to the solutions driven by higher-resolution atmospheric conditions, most of the changes result in more realistic simulations. A better simulation of the effect of the ocean on ice shelf basal melt would likely occur with small enough ocean 
grid spacing to allow eddies on the Antarctic continental shelves, which have been shown to deliver significant heat across the shelf. Furthermore, adding tidal flow may also increase the rate of basal melt by increasing the heat exchange between the ocean and the ice shelf. Finally, the PWRF simulation is driven by a fixed SST and sea ice extent. A coupled simulation may lead to significantly different ocean, sea ice, and atmospheric states in the coastal regions. These coupled calculations are now being made as part of the ACCIMA project.

Acknowledgments. This research was supported by the National Science Foundation under Grants ANT-1048989 to ODU, ANT-1049089 to OSU, and ANT-1049081 to NYU. NYU Abu Dhabi research institute contributed through Grant G1204. Comments from Julien Nicolas and three reviewers greatly improved this manuscript.

\section{REFERENCES}

Adler, R. F., and Coauthors, 2003: The Version 2 Global Precipitation Climatology Project (GPCP) Monthly Precipitation Analysis (1979-present). J. Hydrometeor., 4, 1147-1167, doi:10.1175/ 1525-7541(2003)004<1147:TVGPCP > 2.0.CO;2.

Arrigo, K. R., K. E. Lowry, and G. L. van Dijken, 2012: Annual changes in sea ice and phytoplankton in polynyas of the Amundsen Sea, Antarctica. Deep-Sea Res. II, 71-76, 5-15, doi:10.1016/j.dsr2.2012.03.006.

Årthun, M., P. R. Holland, K. W. Nicholls, and D. L. Feltham, 2013: Eddy-driven exchange between the open ocean and a subice shelf cavity. J. Phys. Oceanogr., 43, 2372-2387, doi:10.1175/ JPO-D-13-0137.1.

Arzeno, I. B., R. C. Beardsley, R. Limeburner, B. Owens, L. Padman, S. R. Springer, C. L. Stewart, and M. J. M. Williams, 2014: Ocean variability contributing to basal melt rate near the ice front of Ross Ice Shelf, Antarctica. J. Geophys. Res., 119, 4214-4233, doi:10.1002/2014JC009792.

Assmann, K. M., A. Jenkins, D. R. Shoosmith, D. P. Walker, S. S. Jacobs, and K. W. Nicholls, 2013: Variability of circumpolar deep water transport onto the Amundsen Sea continental shelf through a shelf break trough. J. Geophys. Res., 118, 66036620, doi:10.1002/2013JC008871.

Bracegirdle, T. J., and G. J. Marshall, 2012: The reliability of Antarctic tropospheric pressure and temperature in the latest global reanalyses. J. Climate, 25, 7138-7146, doi:10.1175/JCLI-D-11-00685.1.

Bromwich, D. H., and D. D. Kurtz, 1984: Katabatic wind forcing of the Terra Nova Bay polynya. J. Geophys. Res., 89, 3561-3572, doi:10.1029/JC089iC03p03561.

, J. F. Carrasco, Z. Liu, and R.-Y. Tzeng, 1993: Hemispheric atmospheric variations and oceanographic impacts associated with katabatic surges across the Ross Ice Shelf. J. Geophys. Res., 98, 13 045-13 062, doi:10.1029/93JD00562.

— Z. Liu, A. N. Rogers, and M. L. Van Woert, 1998: Winter atmospheric forcing of the Ross Sea polynya. Ocean, Ice and Atmosphere: Interactions at the Antarctic Continental Margin, S. S. Jacobs and R. F. Weiss, Eds., Antarctic Research Series, Vol. 75, Amer. Geophys. Union, 101-133.

— A. J. Monaghan, K. W. Manning, and J. G. Powers, 2005: Real-time forecasting for the Antarctic: An evaluation of the
Antarctic Mesoscale Prediction System (AMPS). Mon. Wea. Rev., 133, 579-603, doi:10.1175/MWR-2881.1.

_ , F. O. Otieno, K. M. Hines, K. W. Manning, and E. Shilo, 2013: Comprehensive evaluation of polar weather research and forecasting performance in the Antarctic. J. Geophys. Res. Atmos., 118, 274-292, doi:10.1029/2012JD018139.

Budgell, P., 2005: Numerical simulation of ice-ocean variability in the Barents Sea region towards dynamical downscaling. Ocean Dyn., 55, 370-387, doi:10.1007/s10236-005-0008-3.

Carton, J. A., and B. A. Giese, 2008: A reanalysis of ocean climate using SODA. Mon. Wea. Rev., 136, 2999-3017, doi:10.1175/ 2007MWR1978.1.

Carvajal, G. K., A. K. Wåhlin, L. E. B. Eriksson, and L. M. H. Ulander, 2013: Correlation between synthetic aperture radar surface winds and deep water velocity in the Amundsen Sea, Antarctica. Remote Sens., 5, 4088-4106, doi:10.3390/rs5084088.

Chen, J. L., C. R. Wilson, D. Blakenship, and B. D. Tapley, 2009: Accelerated Antarctic ice loss from satellite gravity measurements. Nat. Geosci., 2, 859-862, doi:10.1038/ngeo694.

Comiso, J. C., 2010: Polar Oceans from Space. Springer, 507 pp.

Corr, H. F. J., A. Jenkins, K. W. Nicholls, and C. S. M. Doake, 2002: Precise measurement of changes in ice-shelf thickness by phase-sensitive radar to determine basal melt rates. Geophys. Res. Lett., 29, doi:10.1029/2001GL014618.

Cunningham, S. A., S. G. Alderson, B. A. King, and M. A. Brandon, 2003: Transport and variability of the Antarctic Circumpolar Current in Drake Passage. J. Geophys. Res., 108, 8084, doi:10.1029/2001JC001147.

DeAngelis, H., and P. Skvarca, 2003: Glacier surge after ice shelf collapse. Science, 299, 1560-1562, doi:10.1126/science.1077987.

Dee, D. P., and Coauthors, 2011: The ERA-Interim reanalysis Configuration and performance of the data assimilation system. Quart. J. Roy. Meteor. Soc., 137, 553-597, doi:10.1002/qj.828.

Depoorter, M. A., J. L. Bamber, J. A. Griggs, J. T. M. Lenaerts, S. R. M. Ligtenberg, M. R. van den Broeke, and G. Moholdt, 2013: Calving fluxes and basal melt rates of Antarctic ice shelves. Nature, 502, 89-92, doi:10.1038/nature12567.

Dinniman, M. S., J. M. Klinck, and W. O. Smith Jr., 2007: The influence of sea ice cover and icebergs on circulation and water mass formation in a numerical circulation model of the Ross Sea, Antarctica. J. Geophys. Res., 112, C11013, doi:10.1029/ 2006JC004036.

,-- , and - 2011: A model study of Circumpolar Deep Water on the West Antarctic Peninsula and Ross Sea continental shelves. Deep-Sea Res. II, 58, 1508-1523, doi:10.1016/ j.dsr2.2010.11.013.

- — - and E. E. Hofmann, 2012: Sensitivity of Circumpolar Deep Water transport and ice shelf basal melt along the west Antarctic Peninsula to changes in the winds. J. Climate, 25, 4799-4816, doi:10.1175/JCLI-D-11-00307.1.

Dupont, T. K., and R. B. Alley, 2005: Assessment of the importance of ice-shelf buttressing to ice-sheet flow. Geophys. Res. Lett., 32, L04503, doi:10.1029/2004GL022024.

Fairall, C. W., E. F. Bradley, J. E. Hare, A. A. Grachev, and J. B. Edson, 2003: Bulk parameterization of air-sea fluxes: Updates and verification for the COARE algorithm. J. Climate, 16, 571591, doi:10.1175/1520-0442(2003)016<0571:BPOASF $>2.0 . C O ; 2$

Flather, R. A., 1976: A tidal model of the north-west European continental shelf. Mem. Soc. Roy. Sci. Liege, Ser. 6, 10,141161.

Foldvik, A., and T. Kvinge, 1974: Conditional instability of sea water at the freezing point. Deep-Sea Res. Oceanogr. Abstr. 21, 229-243, doi:10.1016/0011-7471(74)90056-4. 
Galton-Fenzi, B. K., J. R. Hunter, R. Coleman, S. J. Marsland, and R. C. Warner, 2012: Modeling the basal melting and marine ice accretion of the Amery Ice Shelf. J. Geophys. Res., 117, C09031, doi:10.1029/2012JC008214.

Glisan, J. M., W. J. Gutowski, J. J. Cassano, and M. E. Higgins, 2013: Effects of spectral nudging in WRF on Arctic temperature and precipitation simulations. J. Climate, 26, 3985-3999, doi:10.1175/JCLI-D-12-00318.1.

Haid, V., and R. Timmermann, 2013: Simulated heat flux and sea ice production at coastal polynyas in the southwestern Weddell Sea. J. Geophys. Res. Oceans, 118, 2640-2652, doi:10.1002/jgrc. 20133.

Haidvogel, D. B., and Coauthors, 2008: Ocean forecasting in terrain-following coordinates: Formulation and skill assessment of the Regional Ocean Modeling System. J. Comput. Phys., 227, 3595-3624, doi:10.1016/j.jcp.2007.06.016.

Häkkinen, S., and G. L. Mellor, 1992: Modeling the seasonal variability of a coupled arctic ice-ocean system. J. Geophys. Res., 97, 20 285-20 304, doi:10.1029/92JC02037.

Hallberg, R., 2013: Using a resolution function to regulate parameterizations of oceanic mesoscale eddy effects. Ocean Modell., 72, 92-103, doi:10.1016/j.ocemod.2013.08.007.

Hattermann, T., O. A. Nøst, J. M. Lilly, and L. H. Smedsrud, 2012: Two years of oceanic observations below the Fimbul Ice Shelf, Antarctica. Geophys. Res. Lett., 39, L12605, doi:10.1029/ 2012GL051012.

Hellmer, H. H., 2004: Impact of Antarctic ice shelf basal melting on sea ice and deep ocean properties. Geophys. Res. Lett., 31, L10307, doi:10.1029/2004GL019506.

— - S. S. Jacobs, and A. Jenkins, 1998: Oceanic erosion of a floating Antarctic glacier in the Amundsen Sea. Ocean, Ice, and Atmosphere: Interactions at the Antarctic Continental Margin, S. S. Jacobs and R. F. Weiss, Eds., Antarctic Research Series, Vol. 75, Amer. Geophys. Union, 83-99.

- , O. Huhn, D. Gomis, and R. Timmermann, 2011: On the freshening of the northwestern Weddell Sea continental shelf. Ocean Sci., 7, 305-316, doi:10.5194/os-7-305-2011.

Hines, K. M., D. H. Bromwich, L. Bai, C. M. Bitz, J. G. Powers, and K. W. Manning, 2015: Sea ice enhancements to polar WRF. Mon Wea. Rev., 143, 2363-2385, doi:10.1175/MWR-D-14-00344.1.

Hofmann, E. E., and J. M. Klinck, 1998: Hydrography and circulation of the Antarctic continental shelf: $150^{\circ} \mathrm{E}$ to the Greenwich Meridian. The Global Coastal Ocean: Regional Studies and Syntheses, A. R. Robinson and K. H. Brink, Eds., The Sea-Ideas and Observations on Progress in the Study of the Seas, Vol. 11, John Wiley and Sons, 997-1042.

Holland, D. M., and A. Jenkins, 1999: Modelling thermodynamic ice-ocean interactions at the base of an ice shelf. J. Phys. Oceanogr., 29, 1787-1800, doi:10.1175/1520-0485(1999)029<1787: MTIOIA $>2.0 . \mathrm{CO} ; 2$.

Holland, P. R., A. Jenkins, and D. M. Holland, 2010: Ice and ocean processes in the Bellingshausen Sea, Antarctica. J. Geophys. Res., 115, C05020, doi:10.1029/2008JC005219.

Hollands, T., V. Haid, W. Dierking, R. Timmermann, and L. Ebner, 2013: Sea ice motion and open water area at the Ronne Polynya, Antarctica: Synthetic aperture radar observations versus model results. J. Geophys. Res Oceans., 118, 1940-1954, doi:10.1002/jgrc.20158.

Hunke, E. C., 2001: Viscous-plastic sea ice dynamics with the EVP model: Linearization issues. J. Comput. Phys., 170, 18-38, doi:10.1006/jcph.2001.6710.

__ and J. K. Dukowicz, 1997: An elastic-viscous-plastic model for sea ice dynamics. J. Phys. Oceanogr., 27, 1849-1867, doi:10.1175/1520-0485(1997)027<1849:AEVPMF>2.0.CO;2.
Jacobs, S. S., and J. C. Comiso, 1989: Sea ice and oceanic processes on the Ross Sea continental shelf. J. Geophys. Res., 94, 18195 18 211, doi:10.1029/JC094iC12p18195.

— , and C. F. Giulivi, 2010: Large multidecadal salinity trends near the Pacific-Antarctic continental margin. J. Climate, 23, 4508-4524, doi:10.1175/2010JCLI3284.1.

- H. H. Helmer, C. S. M. Doake, A. Jenkins, and R. M. Frolich, 1992: Melting of ice shelves and the mass balance of Antarctica. J. Glaciol., 38, 375-387.

, H. H. Hellmer, and A. Jenkins, 1996: Antarctic ice sheet melting in the southeast Pacific. Geophys. Res. Lett., 23, 957960, doi:10.1029/96GL00723.

, A. Jenkins, C. F. Giulivi, and P. Dutrieux, 2011: Stronger ocean circulation and increased melting under Pine Island Glacier ice shelf. Nat. Geosci., 4, 519-523, doi:10.1038/ngeo1188.

- - - H. Hellmer, C. Giulivi, F. Nitsche, B. Huber, and R. Guerrero, 2012: The Amundsen Sea and the Antarctic ice sheet. Oceanography, 25, 154-163, doi:10.5670/oceanog.2012.90.

- C. Giulivi, P. Dutrieux, E. Rignot, F. Nitsche, and J. Mouginot, 2013: Getz Ice Shelf melting response to changes in ocean forcing. J. Geophys. Res. Oceans, 118, 4152-4168, doi:10.1002/jgrc. 20298.

Jenkins, A., and S. S. Jacobs, 2008: Circulation and melting beneath George VI Ice Shelf, Antarctica. J. Geophys. Res., 113, C04013, doi:10.1029/2007JC004449.

, D. G. Vaughan, S. S. Jacobs, H. H. Hellmer, and J. R. Keys, 1997: Glaciological and oceanographic evidence of high melt rates beneath Pine Island Glacier, west Antarctica. J. Glaciol., 43, 114-121.

, P. Dutrieux, S. S. Jacobs, S. D. McPhail, J. R. Perrett, A. T. Webb, and D. White, 2010: Observations beneath Pine Island Glacier in West Antarctica and implications for its retreat. Nat. Geosci., 3, 468-472, doi:10.1038/ngeo890.

Klinck, J. M., and M. S. Dinniman, 2010: Exchange across the shelf break at high southern latitudes. Ocean Sci., 6, 513-524, doi:10.5194/os-6-513-2010.

Koenig, Z., C. Provost, R. Ferrari, N. Sennéchael, and M.-H. Rio, 2014: Volume transport of the Antarctic Circumpolar Current: Production and validation of a 20 year long time series obtained from in situ and satellite observations. J. Geophys. Res. Oceans, 119, 5407-5433, doi:10.1002/2014JC009966.

Kottmeier, C., and D. Engelbart, 1992: Generation and atmospheric heat exchange of coastal polynyas in the Weddell Sea. Bound.-Layer Meteor., 60, 207-234, doi:10.1007/BF00119376.

Kusahara, K., and H. Hasumi, 2013: Modeling Antarctic ice shelf responses to future climate changes and impacts on the ocean. J. Geophys. Res. Oceans, 118, 2454-2475, doi:10.1002/jgrc.20166.

Langley, K., and Coauthors, 2014: Low melt rates with seasonal variability at the base of Fimbul Ice Shelf, East Antarctica, revealed by in situ interferometric radar measurements. Geophys. Res. Lett., 41, 8138-8146, doi:10.1002/2014GL061782.

Large, W. G., J. C. McWilliams, and S. C. Doney, 1994: Oceanic vertical mixing: A review and a model with nonlocal boundary layer parameterization. Rev. Geophys., 32, 363-403, doi:10.1029/94RG01872.

Li, M., J. Liu, Z. Wang, H. Wang, Z. Zhang, L. Zhang, and Q. Yang, 2013: Assessment of sea surface wind from NWP reanalyses and satellites in the Southern Ocean. J. Atmos. Oceanic Technol., 30, 1842-1853, doi:10.1175/JTECH-D-12-00240.1.

Locarnini, R. A., A. V. Mishonov, J. I. Antonov, T. P. Boyer, H. E. Garcia, O. K. Baranova, M. M. Zweng, and D. R. Johnson, 2010: Temperature. Vol. 1, World Ocean Atlas 2009, NOAA Atlas NESDIS 68, 184 pp. 
Loose, B., P. Schlosser, W. M. Smethie, and S. Jacobs, 2009: An optimized estimate of glacial melt from the Ross Ice Shelf using noble gases, stable isotopes, and CFC transient tracers. J. Geophys. Res., 114, C08007, doi:10.1029/2008JC005048.

Makinson, K., P. R. Holland, A. Jenkins, K. W. Nicholls, and D. M. Holland, 2011: Influence of tides on melting and freezing beneath Filchner-Ronne Ice Shelf, Antarctica. Geophys. Res. Lett., 38, L06601, doi:10.1029/2010GL046462.

Marchesiello, P., J. C. McWilliams, and A. Shchepetkin, 2001: Open boundary condition for long-term integration of regional oceanic models. Ocean Modell., 3, 1-20, doi:10.1016/ S1463-5003(00)00013-5.

Markus, T., C. Kottmeier, and E. Fahrbach, 1998: Ice formation in coastal polynyas in the Weddell Sea and their impact on oceanic salinity. Antarctic Sea Ice: Physical Processes, Interactions and Variability, M. O. Jeffries, Ed., Antarctic Research Series, Vol. 74, Amer. Geophys. Union, 273-292.

Martinsen, E. H., and H. Engedahl, 1987: Implementation and testing of a lateral boundary scheme as an open boundary condition in a barotropic ocean model. Coastal Eng., 11, 603 627, doi:10.1016/0378-3839(87)90028-7.

Massom, R. A., P. T. Harris, K. J. Michael, and M. J. Potter, 1998: The distribution and formative processes of latent-heat polynyas in east Antarctica. Ann. Glaciol., 27, 420-426.

Mathiot, P., N. C. Jourdain, B. Barnier, H. Gallée, J. M. Molines, J. Le Sommer, and T. Penduff, 2012: Sensitivity of coastal polynyas and high-salinity shelf water production in the Ross Sea, Antarctica, to the atmospheric forcing. Ocean Dyn., 62, 701-723, doi:10.1007/s10236-012-0531-y.

McMillan, M., A. Shepherd, A. Sundal, K. Briggs, A. Muir, A. Ridout, A. Hogg, and D. Wingham, 2014: Increased ice losses from Antarctica detected by CryoSat-2. Geophys. Res. Lett., 41, 3899-3905, doi:10.1002/2014GL060111.

Mellor, G. L., and L. Kantha, 1989: An ice-ocean coupled model. J. Geophys. Res., 94, 10 937-10 954, doi:10.1029/JC094iC08p10937.

Menemenlis, D., J.-M. Campin, P. Heimbach, C. Hill, T. Lee, A. Nguyen, M. Schodlock, and H. Zhang, 2008: ECCO2: High resolution global ocean and sea ice data synthesis. Mercator Ocean Quarterly Newsletter, No. 31, Mercator-Ocean, Ramonville, Saint-Agne, France, 13-21.

Morales Maqueda, M. A., A. J. Willmott, and N. R. T. Biggs, 2004: Polynya dynamics: A review of observations and modeling. Rev. Geophys., 42, RG1004, doi:10.1029/2002RG000116.

Mueller, R. D., L. Padman, M. S. Dinniman, S. Y. Erofeeva, H. A. Fricker, and M. A. King, 2012: Impact of tide-topography interactions on basal melting of Larsen C Ice Shelf, Antarctica. J. Geophys. Res., 117, C05005, doi:10.1029/2011JC007263.

Nakayama, Y., R. Timmermann, M. Schröder, and H. H. Hellmer, 2014: On the difficulty of modeling Circumpolar Deep Water intrusions onto the Amundsen Sea continental shelf. Ocean Modell., 84, 26-34, doi:10.1016/j.ocemod.2014.09.007.

Nicholls, K. W., and K. Makinson, 1998: Ocean circulation beneath the western Ronne Ice Shelf, as derived from in situ measurements of water currents and properties. Ocean, Ice, and Atmosphere: Interactions at the Antarctic Continental Margin, S. S. Jacobs and R. F. Weiss, Eds., Antarctic Research Series, Vol. 75, Amer. Geophys. Union, 301-318.

— L. Padman, M. Schröder, R. A. Woodgate, A. Jenkins, and S. Østerhus, 2003: Water mass modification over the continental shelf north of Ronne Ice Shelf, Antarctica. J. Geophys. Res., 108, 3260, doi:10.1029/2002JC001713.

_ , S. Østerhus, K. Makinson, T. Gammerlsrød, and E. Fahrback, 2009: Ice-ocean processes over the continental shelf of the southern Weddell Sea, Antarctica: A review. Rev. Geophys., 47, RG3003, doi:10.1029/2007RG000250.

Niiler, P. P., and E. B. Kraus, 1977: One-dimensional models of the upper ocean. Modeling and Prediction of the Upper Layers of the Ocean, E. B. Krauss, Ed., Pergamon, 143-172.

Orsi, A. H., T. Whitworth III, and W. D. Nowlin Jr., 1995: On the meridional extent and fronts of the Antarctic Circumpolar Current. Deep-Sea Res. I, 42, 641-673, doi:10.1016/ 0967-0637(95)00021-W.

Padman, L., and Coauthors, 2012: Oceanic controls on mass balance of Wilkins Ice Shelf, Antarctica. J. Geophys. Res., 117, C01010, doi:10.1029/2011JC007301.

Parish, T. R., and D. H. Bromwich, 2007: Re-examination of the near-surface air flow over the Antarctic continent and implications on atmospheric circulations at high southern latitudes. Mon. Wea. Rev., 135, 1961-1973, doi:10.1175/ MWR3374.1.

- J. J. Cassano, and M. W. Seefeldt, 2006: Characteristics of the Ross Ice Shelf air stream as depicted in Antarctic Mesoscale Prediction System simulations. J. Geophys. Res., 111, D12109, doi:10.1029/2005JD006185

Payne, A. J., A. Vieli, A. Shepherd, D. J. Wingham, and E. Rignot, 2004: Recent dramatic thinning of largest West Antarctic ice stream triggered by oceans. Geophys. Res. Lett., 31, L23401, doi:10.1029/2004GL021284.

Petrelli, P., N. L. Bindoff, and A. Bergamasco, 2008: The sea ice dynamics of Terra Nova Bay and Ross Ice Shelf Polynyas during a spring and winter simulation. J. Geophys. Res., 113, C09003, doi:10.1029/2006JC004048.

Petty, A. A., P. R. Holland, and D. L. Feltham, 2014: Sea ice and the ocean mixed layer over the Antarctic shelf seas. Cryosphere, 8, 761-783, doi:10.5194/tc-8-761-2014.

Potter, J. R., and J. G. Paren, 1985: Interaction between ice shelf and ocean in George VI Sound, Antarctica. Oceanology of the Antarctic Continental Shelf, S. S. Jacobs, Ed., Antarctic Research Series, Vol. 43, Amer. Geophys. Union, 35-58.

Pritchard, H. D., R. J. Arthern, D. G. Vaughan, and L. A. Edwards, 2009: Extensive dynamic thinning on the margins of the Greenland and Antarctic ice sheets. Nature, 461, 971-975, doi:10.1038/nature08471.

_, S. R. M. Ligtenberg, H. A. Fricker, D. G. Vaughan, M. R. van den Broeke, and L. Padman, 2012: Antarctic ice-sheet loss driven by basal melting of ice shelves. Nature, 484, 502-505, doi:10.1038/nature10968.

Rignot, E., 1998: Fast recession of a West Antarctic glacier. Science, 281, 549-551, doi:10.1126/science.281.5376.549.

— Eos, Trans. Amer. Geophys. Union, 89 (Fall Meeting Suppl.), Abstract C41D-02.

, I. Velicogna, M. R. van den Broeke, A. Monaghan, and J. T. M. Lenaerts, 2011: Acceleration of the contribution of the Greenland and Antarctic ice sheets to sea level rise. Geophys. Res. Lett., 38, L05503, doi:10.1029/2011GL046583.

_ S. Jacobs, J. Mouginot, and B. Scheuchl, 2013: Ice shelf melting around Antarctica. Science, 341, 266-270, doi:10.1126/ science. 1235798 .

Robertson, R., 2013: Tidally induced increases in melting of Amundsen Sea ice shelves. J. Geophys. Res. Oceans, 118, 3138-3145, doi:10.1002/jgrc.20236.

Rossow, W. B., A. W. Walker, D. E. Beuschel, and M. D. Roiter, 1996: International Satellite Cloud Climatology Project (ISCCP) documentation of new cloud datasets. WMO/TD737, World Meteorological Organization, $115 \mathrm{pp}$. 
Sanz Rodrigo, J., J.-M. Buchlin, J. van Beeck, J. T. M. Lenaerts, and M. R. van den Broeke, 2013: Evaluation of the Antarctic surface wind climate from ERA reanalyses and RACMO2/ ANT simulations based on automatic weather stations. Climate Dyn., 40, 353-376, doi:10.1007/s00382-012-1396-y.

Schodlok, M. P., D. Menemenlis, E. Rignot, and M. Studinger, 2012: Sensitivity of the ice-shelf/ocean system to the sub-iceshelf cavity shape measured by NASA IceBridge in Pine Island Glacier, West Antarctica. Ann. Glaciol., 53, 156-162, doi:10.3189/2012AoG60A073.

Schoof, C., 2007: Ice sheet grounding line dynamics: Steady states, stability and hysteresis. J. Geophys. Res., 112, F03S28, doi:10.1029/ 2006JF000664.

Shchepetkin, A. F., and J. C. McWilliams, 2009: Correction and commentary for "Ocean forecasting in terrain-following coordinate: Formulation and skill assessment of the regional ocean modeling system" by Haidvogel et al., J. Comp. Phys. 227, pp. 3595-3624. J. Comput. Phys., 228, 8985-9000, doi:10.1016/ j.jcp.2009.09.002.

Shepherd, A., D. J. Wingham, and E. Rignot, 2004: Warm ocean is eroding West Antarctic Ice Sheet. Geophys. Res. Lett., 31, L23402, doi:10.1029/2004GL021106.

Smethie, W. M., and S. S. Jacobs, 2005: Circulation and melting under the Ross Ice Shelf: Estimates from evolving CFC, salinity and temperature fields in the Ross Sea. Deep-Sea Res. I, 52, 959-978, doi:10.1016/j.dsr.2004.11.016.

Smith, W. O., Jr., M. S. Dinniman, E. E. Hofmann, and J. M. Klinck, 2014: The effects of changing winds and temperatures on the oceanography of the Ross Sea in the 21st century. Geophys. Res. Lett., 41, 1624-1631, doi:10.1002/2014GL059311.

Spence, P., S. M. Griffies, M. H. England, A. M. C. Hogg, O. A. Saenko, and N. C. Jourdain, 2014: Rapid subsurface warming and circulation changes of Antarctic coastal waters by poleward shifting winds. Geophys. Res. Lett., 41, 4601-4610, doi:10.1002/ 2014GL060613.

St-Laurent, P., J. M. Klinck, and M. S. Dinniman, 2013: On the role of coastal troughs in the circulation of warm circumpolar deep water on Antarctic shelves. J. Phys. Oceanogr., 43, 51-64, doi:10.1175/JPO-D-11-0237.1.

Steele, M., G. L. Mellor, and M. G. McPhee, 1989: Role of the molecular sublayer in the melting or freezing of sea ice. J. Phys.
Oceanogr., 19, 139-147, doi:10.1175/1520-0485(1989)019<0139: ROTMSI $>2.0 . C O ; 2$.

Stern, A. A., M. S. Dinniman, V. Zagorodnov, S. W. Tyler, and D. M. Holland, 2013: Intrusion of warm surface water beneath the McMurdo Ice Shelf, Antarctica. J. Geophys. Res. Oceans, 118, 7036-7048, doi:10.1002/2013JC008842.

Talbot, M. H., 1988: Oceanic environment of George VI Ice Shelf, Antarctic Peninsula. Ann. Glaciol., 11, 161-164.

Thoma, M., A. Jenkins, D. Holland, and S. Jacobs, 2008: Modelling Circumpolar Deep Water intrusions on the Amundsen Sea continental shelf. Geophys. Res. Lett., 35, L18602, doi:10.1029/ 2008GL034939.

Timmermann, R., and Coauthors, 2010: A consistent data set of Antarctic ice sheet topography, cavity geometry, and global bathymetry. Earth Syst. Sci. Data, 2, 261-273, doi:10.5194/ essd-2-261-2010.

, Q. Wang, and H. H. Hellmer, 2012: Ice-shelf basal melting in a global finite-element sea-ice/ice-shelf/ocean model. Ann. Glaciol., 53, 303-314, doi:10.3189/2012AoG60A156.

Velicogna, I., 2009: Increasing rates of ice mass loss from the Greenland and Antarctic ice sheets revealed by GRACE. Geophys. Res. Lett., 36, L19503, doi:10.1029/2009GL040222.

Wåhlin, A. K., and Coauthors, 2013: Variability of warm deep water inflow in a submarine trough on the Amundsen Sea shelf. J. Phys. Oceanogr., 43, 2054-2070, doi:10.1175/ JPO-D-12-0157.1.

Wen, J., Y. Wang, W. Wang, K. C. Jezek, H. Liu, and I. Allison, 2010: Basal melting and freezing under the Amery Ice Shelf, East Antarctica. J. Glaciol., 56, 81-90, doi:10.3189/ 002214310791190820.

Yu, J., H. Liu, K. C. Jezek, R. C. Warner, and J. Wen, 2010: Analysis of velocity field, mass balance, and basal melt of the Lambert Glacier-Amery Ice Shelf system by incorporating Radarsat SAR interferometry and ICESat laser altimetry measurements. J. Geophys. Res., 115, B11102, doi:10.1029/ 2010JB007456.

Zwally, H. J., J. C. Comiso, and A. L. Gordon, 1985: Antarctic offshore leads and polynyas and oceanographic effects. Oceanology of the Antarctic Continental Shelf, S. S. Jacobs, Ed., Antarctic Research Series, Vol. 43, Amer. Geophys. Union, 203-226. 